\title{
Comparing orthomagmatic and hydrothermal mineralization models for komatiite-hosted nickel deposits in Zimbabwe using multiple-sulfur, iron, and nickel isotope data
}

\author{
Axel Hofmann ${ }^{1,{ }^{*}}$, Andrey Bekker ${ }^{2,3}$, Paul Dirks ${ }^{4}$, Bleuenn Gueguen ${ }^{5,6}$, Doug Rumble ${ }^{3}$, \\ Olivier J. Rouxel ${ }^{6}$
}

\author{
${ }^{1}$ Department of Geology, University of Johannesburg, Auckland Park, 2006, South Africa \\ 2 Department of Geological Sciences, University of Manitoba, Winnipeg, MB, R3T 2N2, Canada \\ ${ }^{3}$ Geophysical Laboratory, Carnegie Institution, Washington, DC, 20015, USA \\ ${ }^{4}$ School of Earth and Environmental Sciences, James Cook University, Townsville, QLD, 4812, Australia \\ 5 Technopôle Brest-Iroise, European Institute for Marine Studies, University of Brest, UEB, Place Nicolas \\ Copernic, 29280, Plouzané, France \\ ${ }^{6}$ IFREMER, Centre de Brest, 29280, Plouzané, France
}

*: Corresponding author : Axel Hofmann, email address : ahofmann@uj.ac.za

\begin{abstract}
:
Trojan and Shangani mines are low-grade $(<0.8 \% \mathrm{Ni})$, komatiite-hosted nickel sulfide deposits associated with ca. $2.7 \mathrm{Ga}$ volcano-sedimentary sequences of the Zimbabwe craton. At both mines, nickel sulfide mineralization is present in strongly deformed serpentinite bodies that are enveloped by a complex network of highly sheared, silicified, and sulfide-bearing metasedimentary rocks. Strong, polyphase structural-metamorphic-metasomatic overprints in both the Trojan and Shangani deposits make it difficult to ascertain if sulfide mineralization was derived from orthomagmatic or hydrothermal processes, or by a combination of both. Multiple $\mathrm{S}, \mathrm{Fe}$, and $\mathrm{Ni}$ isotope analyses were applied to test these competing models. Massive ores at Shangani Mine show mass-dependent fractionation of sulfur isotopes consistent with a mantle sulfur source, whereas S-isotope systematics of net-textured ore and disseminated ore in talcose serpentinite indicates mixing of magmatic and sedimentary sulfur sources, potentially via post-magmatic hydrothermal processes. A restricted range of strongly massindependent $\Delta^{33} S$ values in ore samples from Trojan Mine likely reflects high-temperature assimilation of sulfur from supracrustal rocks and later superimposed low-temperature hydrothermal remobilization. Iron isotope values for most Ni-bearing sulfides show a narrow range suggesting that, in contrast to sulfur, nearly all of iron was derived from an igneous source. Negative $\mathrm{Ni}$ isotope values also agree with derivation of $\mathrm{Ni}$ from ultramafic melt and a significant high-temperature fractionation of $\mathrm{Ni}$ isotopes. Fe isotope values of some samples from Shangani Mine are more fractionated than expected to occur in high-temperature magmatic systems, further suggesting that hydrothermal processes were involved in either low-grade ore formation (liberation of $\mathrm{Ni}$ from olivine by sulfurbearing hydrothermal fluids) or remobilization of existing sulfides potentially inducing secondary $\mathrm{Ni}$ sulfide mineralization.
\end{abstract}


Keywords: Komatiite-hosted nickel deposit ; Zimbabwe craton ; Archean ; Sulfur isotopes ; Iron isotopes ; Nickel isotopes

\section{Introduction}

Komatiite-hosted nickel sulfide deposits are common in Neoarchean greenstone belts of the Yilgarn craton of Western Australia, the Superior Province of North America, and the Zimbabwe craton in southern Africa as well as in Proterozoic greenstone belts of Canada (Naldrett 2004). The Kambalda area of Western Australia is regarded as the type locality for komatiite-hosted nickel sulfide deposits (Lesher 1989; Hronsky and Schodde 2006). Two main types of deposits have been recognized (Lesher 1989; Lesher and Keays 2002; Barnes 2006). Type 1 deposits occur near or along the base of ultramafic volcanic sequences and hypabyssal sills and are considered to result from the separation of an immiscible sulfide liquid from an ultramafic magma (Lesher and Keays 2002; Naldrett 2004; Arndt et al. 2005). Massive sulfides typically occur at the base of ultramafic bodies or within their footwall embayments. Massive ore is commonly overlain by net-textured (= matrix) ore with sulfides surrounding cumulate olivine and pyroxene. Matrix ore is in turn overlain by peridotite or dunite with disseminated sulfide (disseminated ore), which grades into unmineralized, locally spinifex-textured ultramafic rocks toward the stratigraphic top. Mineralization is regarded to have formed at the base of inflated lava flows representing feeder channels for large komatiite flow fields. Sulfides are concentrated at the base of the channels, characterized by cumulate-textured dunites that pass laterally into thin komatiite flow lobes with spinifex texture (Hill et al. 1995). Type 2 deposits are lowgrade disseminations in the central part of cumulate-textured, lenticular dunite bodies. While sulfides may have been precipitated simultaneously with olivine to form interstitial ores (Barnes 2006), some of the $\mathrm{Ni}$ in finely disseminated sulfides may have been derived from subsolidus hydration processes under the influence of sulfur-bearing fluids (Eckstrand 1975; Grguric et al. 2006). 
Most komatiite-hosted nickel deposits are interpreted to have been derived from sulfideundersaturated magmas (Keays, 1995; Naldrett, 2004; Arndt et al., 2005). Sulfide saturation of the magma and the formation of an immiscible sulfide liquid trapping nickel, copper, and platinum-group elements are attributed to the addition of crust-derived sulfur. Sulfide-bearing carbonaceous sedimentary rocks, including shale and chert, sulfidized iron formation, and base-metal barren massive sulfides are commonly intercalated with komatiite flows in mineralized ultramafic sequences (Bavinton, 1981; Hopwood, 1981). The exact relation between nickel sulfide mineralization and the sedimentary horizons has not yet been conclusively resolved, but many authors have suggested that the sulfidic sediments provided the sulfur for the ultramafic magmas to reach sulfide saturation (Lesher, 1989; Naldrett, 1989; Lesher and Burnham, 2001; Bekker et al., 2009). The most commonly inferred model for sulfur contamination of type 1 deposits is by thermal erosion and assimilation or devolatilization of the sulfidic sediments beneath ultramafic lava channels (Huppert et al., 1984; Groves et al., 1986; Naldrett, 2004; Barnes, 2006; Williams et al., 2011). In contrast, some authors argued that thermal erosion of the substrate by ultramafic lava flows is unlikely to occur (Rice and Moore, 2001; Cas and Beresford, 2001). In addition, sulfide-hosting troughs and embayments have been regarded as structural rather than primary footwall features (Cowden, 1988; Cowden and Roberts, 1990; Stone and Archibald, 2004).

A further problem in unraveling the origin of komatiite-hosted nickel deposits is their presence in greenstone belts that experienced multiple episodes of deformation and metamorphism, generally interpreted to have affected already existing mineralization. However, many deposits consist of tabular or elongate ore bodies that are parallel to regional, penetrative linear fabrics, including fold axes, and mineral lineations, which formed during the peak of a dynamic regional metamorphic event at upper greenschist to upper amphibolite facies (e.g. Viljoen et al., 1976; Barrett et al., 1977, Gresham and Loftus-Hills, 1981; Barnes et al., 1988; Lesher, 1989; Stone and Archibald, 2004). It is unlikely that in all these cases deformation was focused along pre-existing primary magmatic linear trends. The co-linearity of ore bodies with regional structural trends (cf. Gresham and Loftus-Hills, 1981; Naldrett, 1981) strongly suggests considerable ore redistribution and, possibly, ore generation in response to dynamic metamorphic and metasomatic processes.

In Zimbabwe (Fig. 1), general aspects of the stratigraphy, ore composition and geochemistry of nickel-sulfide deposits are known (e.g., Shangani Mine, Viljoen et al. 1976; Trojan Mine, Chimimba and Ncube, 1986; Epoch Mine, Baglow, 1986; Hunters Road Deposit, Moubray et al., 1979, Prendergast, 2001; Damba Deposit, Williams, 1979, Killick, 
1986), but a detailed description and interpretation of structures and metamorphic textures formed by regional deformation events is mostly lacking. As a result, all deposits have been interpreted as orthomagmatic (Prendergast, 2003), i.e. the Ni-bearing sulfides crystallized from a melt and did not form during sub-solidus processes. However, every nickel deposit in Zimbabwean greenstone belts is centered on structural discontinuities, such as faults or fold hinges, and an evaluation of the structural and metamorphic imprints on these deposits must be made to fully appreciate what role deformation and metamorphism may have played in affecting these low-grade deposits. Furthermore, it has been shown that many of the sulfidic sedimentary horizons that are associated with mineralized ultramafic volcanics have been intensely sheared (Hofmann et al., 2003), possibly resulting in the redistribution of primary sedimentary to diagenetic sulfides and potentially inducing secondary sulfide mineralization. The spatial association of sulfide-bearing high-strain zones with nickel-sulfide mineralization in komatiites may thus point to a secondary, hydrothermal origin or redistribution/enrichment of at least some of the Ni mineralization. Cases of this type of mineralization are known to exist elsewhere (type 4, Barnes, 2006).

In this paper we present field and petrographic observations from the Trojan and Shangani Ni mines in Zimbabwe in combination with trace element geochemistry and multiple sulfur, nickel, and iron isotope data. We critically evaluate mineralization style and test if multiple S, $\mathrm{Ni}$ and $\mathrm{Fe}$ isotope data can provide constraints on the relative importance of orthomagmatic vs. hydrothermal processes in the generation of komatiite-hosted Ni-sulfide mineralization. The study is focused on Trojan Mine, but multiple $\mathrm{S}, \mathrm{Ni}$, and $\mathrm{Fe}$ isotope data are also presented for the Shangani Mine nickel deposit.

\section{Geology of the Shangani Mine and Ni-sulfide mineralization}

Shangani Mine (Fig. 1) is situated in the Shangani Mineralized Complex of the Shangani greenstone belt (Harrison, 1969) and is associated with the Shangani Layered Ultramafic Complex (SLUC) that intruded into greenstone units assigned to the Lower Bulawayan Group (Fig. 2; Wilson et al., 1995). It is a low-grade type 2 deposit with some occurrences of type 1 massive sulfides. Production at the mine in 2002 was $0.93 \mathrm{Mt} / \mathrm{a}$ of ore at an average grade of $0.48 \%$ nickel (C. Makuni, pers. comm., 2003). The Shangani Mineralized Complex is intrusive into the Esmyangene Formation, a succession of felsic tuffaceous sedimentary rocks and agglomerates that is capped by sulfidic carbonaceous shale (Viljoen et al. 1976; Viljoen 135 and Bernasconi, 1979). It consists of two lobes on both sides of a central stem (Fig. 2B) 136 resulting in a mushroom-shaped body in cross section that was interpreted by Viljoen et al. 
(1976) as a lopolith. Dirks and Sithole (1996) reported a more complex geometry resulting from deformation (Fig. 2C). Their mapping has shown that the ultramafic lobes occur as folded lensoidal bodies within a complex network of highly sheared sedimentary rocks that include carbonaceous and sulfidic cherts, and carbonaceous shale with mylonitic texture. Prendergast (2003) argued for an extrusive origin for the Shangani Mineralized Complex, possibly related to the observation of apparent spinifex texture in a pyroxenite-gabbro layer, features not considered by Viljoen et al. (1976) to represent a true quench texture.

The east and west lobes of the Shangani Mineralized Complex correspond to the Main and Far West ore bodies, respectively. The massive sulfide bodies, which are much better developed in the eastern lobe, generally occur at the assumed stratigraphic base of both lobes, consistent with a magmatic control of mineralization (Viljoen et al. 1976). In contrast, Dirks and Sithole (1996) noted a structural control over the ore bodies since they are highly linear and are parallel to a mineral lineation developed in sheared sedimentary rocks as well as fold axes of several generations of colinear folds.

Sedimentary rocks of the Esmyangene Formation constitute the footwall to the Main and Far West ore bodies and consist of siliceous felsic tuff locally interleaved with carbonaceous shale with abundant pyrite and pyrrhotite. Lenses of layered siliceous tuff and carbonaceous shale occur both along the footwall and hanging wall contacts and within the ultramafic rocks along shear zones (Fig. 2C). Sulfide mineralization is developed within the tuff, especially where it underlies Ni-sulfide mineralization in ultramafic rocks. Sulphide grains in tuff display an orientation parallel to the compositional layering.

The mineralized complex consists of massive green and talcose serpentinites and carbonated talc schist. These rocks are enveloped and interleaved with black shale, chloritic siliceous tuff and chlorite-actinolite schist. Massive green serpentinite occurs throughout the mineralized complex and commonly contains disseminated pyrrhotite and pentlandite, which occur as blebs and trails along the margins of serpentinite patches resembling cumulate textures. The sulfides are intergrown with serpentine and subhedral grains of magnetite. Much of the sulfide is however within carbonate-filled fractures, which also contain abundant magnetite. Talcose serpentinite is more abundant in the eastern lobe of the complex and occurs along shear zones dissecting the massive green serpentinite. Mineralization occurs as either disseminated sulfide or several cm-wide massive sulfide veins. Coarse-grained, carbonated talc schists are associated with the talcose serpentinite and form the most common rock type within the eastern lobe and the stem of the Shangani Mineralized Complex. Disseminated sulfide is rare in carbonated talc schist; instead, sulfides occur either as 
schlieren parallel to foliation or within veins. Sulfide-bearing carbonate veins are common within the rock. The association of sulfides with secondary carbonates indicates sulfide mineralization during carbonatization of the ultramafic rocks, a feature common to low-grade type 2 deposits (Grguric et al., 2006).

\section{Geological Setting of Trojan Mine}

Trojan Mine is the largest nickel producer in Zimbabwe. Mining of this type 1 deposit started in 1968 and production in 2002 was $1.03 \mathrm{Mt} / \mathrm{a}$ of ore at an average grade of $0.62 \%$ nickel (C. Makuni, pers. comm., 2003). The Trojan nickel deposit is hosted by the Upper Bulawayan Group metavolcanic rocks within the southern flank of the Bindura-Shamva greenstone belt (Fig. 3A). The basal unit of the greenstone succession overlies the Chinamora granitoid-gneiss dome along a tectonic contact and is represented by the $2715 \pm 15$ Ma Iron Mask Formation (Jelsma et al., 1996), a sequence of calc-alkaline rhyodacitic volcanic and volcaniclastic rocks that are intercalated with lenses of banded iron formation, chert, conglomerate, and basalt. The overlying Arcturus Formation hosts the Trojan nickel deposit and is a sequence of pillowed and massive tholeiitic basalt, komatiitic basalt, ultramafic schist and serpentinite. The volcanic rocks are intercalated with thin horizons of banded iron formation, chert, slate, sandstone and marble. The Arcturus Formation is overlain by siliciclastic metasedimentary rocks of the Shamvaian Supergroup (Hofmann et al., 2002).

Ultramafic rocks that host the nickel mineralization at Trojan Mine (Fig. 3B) have been interpreted as extrusive komatiitic flows in a consistently $\mathrm{N}$-younging volcano-sedimentary sequence (Chimimba, 1984; Chimimba and Ncube, 1986; Baglow, 1992). Gravity settling within the flows has been described as the dominant means of nickel sulfide concentration with minor remobilization along later shear zones, resulting in localized veins of massive sulfides (Chimimba, 1984; Chimimba and Ncube, 1986; Maiden et al., 1986).

\section{Geology and Ni-sulfide mineralization at Trojan Mine}

\section{Lithological units and structural-metamorphic history}

The lithological units around Trojan Mine form discontinuous blocks with sheared, discordant contacts and sigmoidal outcrop pattern (Fig. 3; Dirks and Jelsma, 1998; Jelsma and Dirks, 2000). Table 1 summarizes lithological, mineralogical and structural features of the rock units. The mineralization is generally associated with cumulate-textured peridotitic to dunitic rocks, altered to serpentinite, that occur as a horizon of partly overlapping lensoidal bodies within a metabasalt sequence (Table 1, Fig. 3B). Near the mine site at Cardiff Hill, 
several stacked serpentinite lenses are tectonically intercalated with metasedimentary units (Fig. 4A). Serpentinite is variably carbonated and silicified. The ultramafic rocks are strongly schistose near lithological contacts and within the mineralized zones, but massive, coarsegrained and cumulate-textured in the center of ultramafic lenses. They have been considered as extrusive flows (Chimimba and Ncube, 1986), and their volcanic origin is supported by the intimate association with metabasalts. However, an intrusive origin as shallow-level sills cannot be discounted.

Layers and lenses composed of a variety of silicified and sulfide-bearing, highly deformed metasedimentary rocks (Table 1) are intercalated with the volcanic rocks. Silicified carbonaceous schist and black chert are confined to the immediate vicinity of ultramafic units (Fig. 4B). The rocks become less silicic both vertically and laterally away from the ultramafic rocks. A vein network of sulfides (mostly pyrrhotite) is common in silicified metasedimentary rocks.

A detailed description of the structural and metamorphic history of the Trojan Mine area was presented in Dirks and Jelsma (1998) and Jelsma and Dirks (2000). These authors differentiated 3 major events that affected the greenstone succession. $\mathrm{D}_{1}$ resulted in a pervasive schistosity $\left(\mathrm{S}_{1}\right)$ that trends between $040^{\circ}$ and $100^{\circ}$ and is steeply dipping towards the NW (Fig. 5A). The intensity of $S_{1}$ is greatest along an anastomosing network of $1-30 \mathrm{~m}$ wide shear zones hosted by silicified metasedimentary rocks (Fig. 3B). $\mathrm{D}_{1}$ shear zones preserve mylonitic features and are associated with a shallowly SW-plunging mineral lineation ( $\mathrm{L}_{1}$, Fig. 5B). $\mathrm{D}_{1}$ was associated with a metamorphic event $\left(\mathrm{M}_{1}\right)$ at lower amphibolite facies metamorphic grade, with a temperature of $\sim 500^{\circ} \mathrm{C}$ and a pressure of 3-4 kbar (Dirks and Jelsma, 1998).

$\mathrm{D}_{2}$ gave rise to a second foliation $\left(\mathrm{S}_{2}\right)$ related to the solid-state emplacement of the Chinamora granite-gneiss dome south of the mine area (Fig. 2A). $\mathrm{S}_{2}$ is a shallow to moderate N-dipping, penetrative schistosity and contains a NE-plunging mineral lineation (L2, Fig. 5B). Metamorphism (M2) reached a grade of $565^{\circ} \mathrm{C}$ and $3.5 \mathrm{kbar}$ at Trojan Mine (Dirks and Jelsma, 1998). Brittle strike-slip faulting during $\mathrm{D}_{3}$ reactivated $\mathrm{D}_{1}$ shear zones. Faulting was accompanied by the brecciation of competent units and the infiltration of sulfide and quartzcarbonate veins.

\section{Structural setting of the ore bodies and mineralization patterns}

All nickel ores at Trojan Mine consist of pyrrhotite and pentlandite with lesser amounts of chalcopyrite, pyrite and, locally, millerite. Disseminated ore (cut-off $<0.4 \% \mathrm{Ni}$, average $0.6 \%$ 
$\mathrm{Ni}$ ) is pervasive and makes up $\sim 95 \%$ of the reserves. The remaining $5 \%$ of the reserves are composed of matrix or net-textured ore (30-40\% sulfides, $4 \% \mathrm{Ni})$ and massive ore $(60-90 \%$ sulfides, $10 \% \mathrm{Ni}$ ). The average $\mathrm{Ni} / \mathrm{Cu}$ ratio is $\sim 15$ (Chimimba, 1984), similar to that in other komatiite-hosted nickel-sulfide deposits (Naldrett, 2004).

Ore is concentrated in a number of ultramafic bodies separated by sheared sedimentary units. Ore bodies currently mined include the Main and Hanging Wall ore bodies (Figs. 3B, 6 and 7). The ore bodies as well as the lenses of ultramafic host rock are elongated. Constructed from mine plans, the average orientations of the long axes of Main, Hanging Wall and Cardiff South ore bodies parallel one another in a general direction of 320/70 (Fig. 5C), which is nearly identical to the intersection lineation between the anastomosing $\mathrm{S}_{1}$ orientations and the primary layering $\mathrm{S}_{0}$ in the area (Fig. 5D). In plan view, the Main Ore Body extends about $100-150 \mathrm{~m}$ along strike with a maximum width of $60-100 \mathrm{~m}$. It is situated along two anastomosing shear zone branches that outline a broad synformal feature (Fig. 7), which has previously been interpreted as a footwall embayment (Chimimba, 1987). This shear zone is not a simple planar feature, but consists of a 20-50 m wide zone of anastomosing branches that envelop lenses of metabasalt, chert, metasediment and feldspathic schist.

The Hanging Wall Ore Body is more irregular and has a strike length of about $200 \mathrm{~m}$ (Figs. 6 and 7). It is underlain and separated from the Main Ore Body by a 20-60 m wide shear zone (Fig. 7) in which lenses of spinifex-textured komatiitic metabasalt, feldspathic schist and metagabbro are present. In places the shear zones are entirely situated within the ultramafic rocks and consist of talc-carbonate schist with high proportions of magnetite and thin quartz veinlets. Small lenses $(<2 \mathrm{~m}$ long) of footwall schist are locally present within the shear zones.

Massive ore occurs near the base of the Main, Hanging Wall and Cardiff South ore bodies. Matrix ore is present as shoots in the Main and Hanging Wall ore bodies. The contacts between massive, matrix and disseminated ores are sharp and parallel to the foliation. With the exception of the Footwall 2 Ore Body, massive and matrix ores are generally restricted to the stratigraphically lower parts of the ultramafic host rock and occur in direct contact with a strongly silicified metasedimentary unit resembling chert. In the Hanging Wall Ore Body, massive ore is only present in the extreme west where it overlies silicified sedimentary rock. Massive ore is absent in places where the sedimentary horizon pinches out (Figs. 6 and 7).

Chimimba and Ncube (1986) reported that the nickel content of disseminated ores gradually decreases from the stratigraphic base to the top of the ultramafic host rocks. However, this is an idealized view as, in general, the Ni-content drops off sharply away from 
the basal massive and matrix ores. In detail, $\mathrm{Ni}$ and $\mathrm{MgO}$ concentrations vary greatly across ultramafic lenses and change sharply across shear zones.

\section{Ore environment}

Massive ore is represented by banded to massive sulfide intervals conformable with the principal tectonic fabric and in places transgressing primary igneous layering (Fig. 7A). Lenses of massive ore contain significant proportions (up to 40\%) of footwall metasedimentary lithologies, carbonate and vein quartz fragments, but no ultramafic host rock fragments. Many footwall rock fragments, including vein quartz, are well-rounded and enveloped by foliated sulfide similar to "durchbewegung" structures (Marshall and Gilligan, 1989) indicative of non-coaxial flow. In places, deformed footwall rock fragments with $D_{1}$ and $\mathrm{D}_{2}$ fabric elements become so abundant that massive ore is more aptly described as breccia ore. The margins of both massive and breccia ore shoots typically contain sulfide veins that extend into the adjacent footwall lithologies. These veins are commonly developed along $\mathrm{D}_{3}$ shear zones.

Massive sulfide ore consists of pyrrhotite with minor chalcopyrite, pyrite and chromite. Pentlandite occurs as grains and exsolution lamellae in pyrrhotite or as small grains along the boundaries of larger pyrrhotite crystals. Pentlandite grain aggregates are common and are elongated parallel to $S_{1}$ and the contact with the wall rock. The proportion of chalcopyrite is the highest in the contact zone with the footwall rock and along the margins of wall rock fragments. The chalcopyrite content also increases in injection veins.

Matrix ore consists of densely disseminated sulfide in an ultramafic host. Pyrrhotite and pentlandite, which are the main sulfide phases, form aggregates that are commonly banded parallel to $\mathrm{S}_{1}$. Chalcopyrite occurs in the matrix as small aggregates elongated parallel to $\mathrm{S}_{1}$. Pyrite occurs as subhedral grains. Magnetite, chromite and carbonate are accessory minerals.

Both the massive and matrix ores are foliated. The foliation is defined by preferred orientation of silicate fragments in the sulfide matrix and silicate inclusions within pyrrhotite grains, orientation of pentlandite bands, shape of matrix-pyrrhotite grains, and cleavage orientation in matrix pyrrhotite and pentlandite grains. Matrix pyrrhotite is generally granoblastic due to post-kinematic recrystallization.

Disseminated sulfides are intergrown with metamorphic alteration products and are present in talc-carbonate schist, talc-antigorite schist and massive serpentinite. They frequently occur as elongated matrix grains or grain aggregates oriented parallel to $\mathrm{S}_{1}$. 
Ore texture

Silicate-sulfide textures and mineralogy in the ore bodies at Trojan Mine generally reflect post-magmatic alteration, mobilization and recrystallization processes. Most sulfides in the metasedimentary schist do not show features consistent with a primary origin. They commonly form veins parallel to and cutting across foliation planes, and occur in pressure shadows of metamorphic minerals or in association with ribbon quartz and quartz veins (Fig. 8). Primary sulfides in the form of nodules in metasedimentary rocks are rare and form a minor part of total sulfide budget at best. The secondary, cross-cutting nature of the sulfides in the metasedimentary rocks is a common feature on the mine scale, as indicated by orientation of massive sulfide veins with respect to foliation and stratification of the footwall rocks (Fig. 7).

Sulfide grains in the ultramafic rocks show a variety of textures, but unequivocal evidence for unrecrystallized, primary, magmatic sulfide has not been observed. Intergrowth of sulfides with serpentine, talc, tremolite, and chlorite in serpentinized ultramafic rocks is common (Fig. 9A). Some sulfide aggregates in serpentinized dunite occur as cross-cutting veins that were apparently formed both before and after the serpentinization process (Figs. 9B and 9C). Sulfides that formed prior to the alteration could represent remobilized primary magmatic sulfides. Metadunites with relict cumulate texture are common towards the core of the disseminated ore bodies (Fig. 7). Magnetite frequently rims olivine, now replaced by serpentine and talc or talc and carbonate, and is commonly intergrown with pyrrhotite and pentlandite. Sulfide-bearing reaction rims along margins of olivine crystals suggest sulfide formation during metamorphic processes (Figs. 9D and 9E). Sulfide globules are commonly aligned along fine cracks both within and interstitial to variably replaced olivine grains likely indicating secondary origin for these globules (Fig. 9F).

\section{Timing of sulfide mobilization relative to deformation}

Textural evidence indicates sulfide mobility during each deformation stage. Sulfur mobility during the initial serpentinization process is indicated by the intergrowth of sulfides and unoriented laths of metamorphic talc, tremolite and antigorite in serpentinite (Fig. 9A). Metamorphism and serpentinization coincided with the development of the penetrative regional foliation and network of shear zones during $\mathrm{D}_{1}$, and many nickel sulfide crystals in disseminated and massive ores are aligned parallel to $S_{1}$. In metasedimentary schist it is common to find sulfide patches parallel to $\mathrm{S}_{1}$, such as in asymmetric pressure shadows around 
porphyroclasts and porphyroblasts (Fig. 8B). During progressive folding of the schist, massive sulfide veins formed parallel to axial planes.

Garnet-bearing schist contains unoriented hornblende patches that are intergrown with sulfides, reflecting sulfide mobility during $\mathrm{D}_{2} / \mathrm{M}_{2}$. Similar relationships exist between sulfides and unoriented antigorite replacing metamorphic olivine (Chimimba, 1987). Most deformation textures in massive and matrix ores appear to post-date $\mathrm{D}_{2}$, considering that blocks of strongly foliated and folded footwall rock fragments and fragments of garnetbearing schist containing unoriented $\mathrm{M}_{2}$ minerals are common within the massive ores. In addition, invasion of sulfide into metasandstone is controlled by $\mathrm{D}_{3}$ brittle-ductile faults.

\section{Analytical procedures}

We analyzed major and trace element contents of selected samples. Fresh-rock samples were reduced with jaw crusher into small chips. Vein-free chips were handpicked, ultrasonically cleaned and pulverized using an agate mill. Major element concentrations were measured by XRF spectrometry (Philips X'Unique XRFS) on glass tablets at the School of Geological Sciences, University of KwaZulu-Natal (UKZN). Accuracy for major elements was checked against international standard NIM-G and was found to be better than $3 \%$.

Trace elements were measured using a Perkin-Elmer Elan 6100 ICP-MS, also at the School of Geological Sciences (UKZN), calibrated against primary standard solutions and validated with certified standard rock materials. $50 \mathrm{mg}$ of sample was dissolved in $\mathrm{HF}-\mathrm{HNO}_{3}$ in an Anton-Paar Multiwave high pressure and temperature microwave digester with 40 minute digestion time and evaporated to dryness in Teflon beakers before being taken up in $5 \% \mathrm{HNO}_{3}$ for analysis. The final solution was topped up to $50 \mathrm{ml}$ for analysis. Internal standards (10 ppb $\mathrm{Rh}, \mathrm{In}, \mathrm{Re}$, and $\mathrm{Bi}$ ) and calibration solutions were prepared from certified single and multielement standard solutions. Quality of data was monitored using the international standards BCR-1, BHVO-1 and BIR-1. For this analysis, precision was better than 5\% except for Sc, V and $\mathrm{Sr}$ (better than 7\%), on the basis of four repeat analysis of BCR-1. Accuracy was better than $15 \%$ for most elements except for $\mathrm{V}, \mathrm{Ni}$ and $\mathrm{Cu}$ (better than 25\%) and $\mathrm{Cr}$ and $\mathrm{Zn}$ (better than $35 \%$ ). Lower limit of detection was typically well below $0.1 \mathrm{ppm}$ for rare earth elements and below 1 ppm for all other elements except for $\mathrm{Cu}$ (below $2.5 \mathrm{ppm}$ ) and $\mathrm{Zn}$ (below 3.7 ppm). One sample (ZTR-1) was analyzed using a Fisons PQ2+ ICP-MS at the University of Queensland, Australia (see Bolhar et al., 2005 for analytical methods and details on accuracy and precision). 
Sulfur isotope ratios were determined at the Geophysical Laboratory, using technique described by $\mathrm{Hu}$ et al. (2003) and under the same analytical conditions as described in Hofmann et al. (2009). The sulfur isotope compositions are reported with respect to VCDT. The intralaboratory precision for $\delta^{34} \mathrm{~S}, \delta^{33} \mathrm{~S}$, and $\Delta^{33} \mathrm{~S}$ values based on multiple $\mathrm{S}$ isotope analysis of CDT material and internal laboratory standards (Maine Light and Alpha Aesar pyrite) is better than $0.34,0.19$, and $0.03 \%$, respectively. Iron isotope and chemical analyses of sulfides were performed on the same aliquots of mineral separates that were used for Sisotope work. Sulfides were digested in Teflon beakers using concentrated $\mathrm{HCl}$ and $\mathrm{HNO}_{3}$ acid mixture and dry residue obtained after evaporation was then dissolved in $6 \mathrm{~N} \mathrm{HCl}$. A fraction of the solution was diluted for $\mathrm{S}, \mathrm{Fe}, \mathrm{Cu}, \mathrm{Ni}$, and $\mathrm{Zn}$ chemical analyses using highresolution ICP-MS or ICP-AES at the Pole Spectrometrie Ocean (PSO, Brest). For each element, instrument sensitivity was calibrated using matrix-matched standard solutions corresponding to synthetic sulfide matrices. The detection limit was better than $0.01 \mathrm{wt} \%$ and analytical precision was estimated at $\sim 2 \%$. Iron isotope ratios were measured on the Neptune multi-collector inductively coupled plasma mass-spectrometer (MC-ICP-MS, Thermo Fisher Scientific; Waltham, MA, USA) operated at the Pole Spectrometrie Ocean (PSO, Brest) following previously published methods (Rouxel et al., 2005, 2008). The MC-ICP-MS was operated in a medium-resolution mode, and we used $\mathrm{Ni}$ as an internal standard for mass bias correction. Fe isotope values are reported relative to the international isotopic standard IRMM-14 using the conventional delta notations. Several georeference materials, including banded iron-formation (IF-G) and Hawaiian Basalt (BHVO-1) standards, were also measured and results were similar to previously reported values (Dauphas and Rouxel, 2006). Based on duplicate chemical purifications and isotope analyses, the long-term external reproducibility is $0.08 \%$ for $\delta^{56} \mathrm{Fe}$ and $0.11 \%$ for $\delta^{57} \mathrm{Fe}$ values ( 2 standard deviations).

$\mathrm{Ni}$ isotopes were measured by MC-ICP-MS (PSO, Brest) using a double-spike method for correction of the instrumental mass bias. The experimental and analytical methods are described in Gueguen et al. (2013). Samples were digested in double-distilled, concentrated $\mathrm{HCl}$ and $\mathrm{HNO}_{3}$. Ni was purified with a two-step column separation procedure using AG1-X8 anionic resin for removal of most $\mathrm{Fe}, \mathrm{Cu}$ and $\mathrm{Zn}$ and a specific resin for $\mathrm{Ni}$ (manufactured by Eichrom) for elution of remaining matrix elements. Prior to loading samples on Ni-spec resin, a known amount of double-spike solution containing ${ }^{61} \mathrm{Ni}$ and ${ }^{62} \mathrm{Ni}$ isotopes was added to the samples. ${ }^{60} \mathrm{Ni} /{ }^{58} \mathrm{Ni}$ ratios are reported in conventional delta notation using the NIST SRM 986 international standard. Pure NIST SRM 986 standard solution was also analyzed during each MC-ICP-MS session in a standard-sample-bracketing manner in order to monitor the external 
error. The error associated with $\mathrm{Ni}$ isotope analyses is $0.02 \%$ ( 2 standard error). It was calculated from the data for 50 measurement cycles performed on each sample during $\mathrm{MC}$ ICP-MS analysis. The double-spike correction method is based on iterative calculations using three isotopic ratios $\left({ }^{60} \mathrm{Ni} /{ }^{58} \mathrm{Ni},{ }^{61} \mathrm{Ni} /{ }^{58} \mathrm{Ni}\right.$, and $\left.{ }^{62} \mathrm{Ni} /{ }^{58} \mathrm{Ni}\right)$ as previously described by Siebert et al. (2001) for Mo isotopes. We estimate that this number of measurement cycles is necessary in order to calculate a satisfactory error on samples.

\section{Geochemistry of metasedimentary horizons at Trojan Mine}

Variably silicified and carbonaceous metasedimentary units were analyzed for their major and trace element contents. These include nine samples of fine-grained siliciclastic rock, representing metamorphosed shale and siltstone, and two samples of metachert. Some samples are from surface exposures, while others were collected from the drillcore 35-1-20 that intersected the main ore body (MOB) and the footwall on the $35^{\text {th }}$ level. For this aspect of our study, samples of metasedimentary rocks with sulfide mineralization were avoided as the focus was on the composition of the siliciclastic material of the rocks. Results of major and selected trace element analyses are presented in Table 2. Analytical procedures are described in the appendix.

Excluding two chert samples, selected element concentrations for the average composition of the samples of siliciclastic metasedimentary rocks normalized to PAAS (post-Archean average Australian shale, Taylor and McLennan, 1985) are plotted in Figure 10. Most elements have concentrations lower than PAAS, possibly due to silicification resulting in apparent element depletion due to silica dilution, as $\mathrm{SiO}_{2}$ content has a large range with values as high as $82 \%$. Compared to PAAS (Fig. 10), $\mathrm{Al}_{2} \mathrm{O}_{3}$ and $\mathrm{TiO}_{2}$ values are relatively low (average $\mathrm{Al}_{2} \mathrm{O}_{3}=13.3 \%$ ). Samples with the highest $\mathrm{Al}_{2} \mathrm{O}_{3}$ contents do not necessarily have the lowest $\mathrm{SiO}_{2}$ contents, as would be expected for siliciclastic sedimentary rocks, again suggesting that the primary mineralogy has been modified by silicification. $\mathrm{Na}_{2} \mathrm{O}$ contents are strongly enriched relative to PAAS, with values as high as $6.9 \%$, indicating albitization. Transition metals correlate positively with each other and with $\mathrm{Fe}_{2} \mathrm{O}_{3}$ content and are generally slightly depleted relative to PAAS, with the exception of $\mathrm{Ni}$, which is slightly enriched, with values as high as $419 \mathrm{ppm}$. Base metals are strongly enriched in the sample set, yielding average values of $212 \mathrm{ppm}$ for $\mathrm{Cu}, 2841 \mathrm{ppm}$ for $\mathrm{Zn}$ and $70 \mathrm{ppm}$ for $\mathrm{Pb}$.

High-field-strength element ratios show a moderate range of variation $(\mathrm{Nb} / \mathrm{Ta}=9-14.4$; $\mathrm{Zr} / \mathrm{Hf}=38-42 ; \mathrm{Th} / \mathrm{U}=1.1-6.3$ ), which possibly suggests contributions from compositionally different sources, but they are generally close to the chondritic values, suggesting no 
significant fractionation as a result of metasomatic or hydrothermal processes during silicification (Bau, 1996). $\Sigma$ REE contents range widely from 46 to $430 \mathrm{ppm}$ and are on average higher than that for PAAS (Fig. 10). There is a moderate positive correlation with $\mathrm{P}_{2} \mathrm{O}_{5}$ content $\left(\mathrm{R}^{2}=0.58\right)$, suggesting a possible control by detrital minerals such as monazite. All samples show LREE enrichment (average $\mathrm{La}_{\mathrm{N}} / \mathrm{Sm}_{\mathrm{N}}=3.81$; Fig. 11), while the HREE are relatively unfractionated (average $\mathrm{Gd}_{N} / \mathrm{Yb}_{N}=1.36$ ). Both negative and positive Eu anomalies $\left(\mathrm{Eu} / \mathrm{Eu}^{*}=0.64-1.99\right)$ are present in the sample set.

Useful and widely employed proxies for the bulk composition of the provenance are the $\mathrm{Cr} / \mathrm{Th}$ and Th/Sc ratios (Condie and Wronkiewicz, 1990; McLennan and Taylor, 1991). The average $\mathrm{Cr} / \mathrm{Th}$ ratio of 14.6 and $\mathrm{Th} / \mathrm{Sc}$ ratio of 0.6 for the siliciclastic metasediments in our study suggest a source of intermediate to felsic composition. A comparison with geochemical data (Tomschi, 1987; Jelsma, 1993) for rhyodacite of the Iron Mask Formation and basalt of the Arcturus Formation, both in terms of REE systematics and $\mathrm{Cr} / \mathrm{Th}$ ratios (Figs. 11 and 12), suggests that a major proportion of the clastic material was derived from a source that may have had a composition intermediate between the two end members. However, this source is unlikely to represent a simple mix of the two lithologies as a result of erosion. An intermediate to felsic volcanic source is also indicated by a large proportion of felsic volcanic detritus in metasandstone intercalated with the metashale. However, difference in composition between the metasedimentary rocks and rhyodacite of the Iron Mask Formation (e.g., the latter have strongly fractionated HREE, see Fig. 11) makes it unlikely that felsic material was simply derived from erosion of stratigraphically underlying rocks. Instead, synsedimentary volcanism providing pyroclastic material of intermediate to felsic volcanic composition seems more likely. Contemporary mafic and felsic volcanism has been reported from several greenstone belts that host Ni-sulfide deposits (Barrie, 1999; Trofimovs et al., 2004).

The chert samples consist predominantly of $\mathrm{SiO}_{2}$ and $\mathrm{Fe}_{2} \mathrm{O}_{3}$ and likely represent either exhalites precipitated at the seafloor or replacement products of siliciclastic sediments. Replacement may have taken place near the sediment-water interface shortly after deposition during hydrothermal activity and silicification, or during later episodes of hydrothermal alteration. Trace element ratios and REE patterns of the cherts are very similar to those of the clastic rocks, suggesting that they do contain minor amounts of compositionally similar detrital material. 
A recent study of several komatiite-hosted Ni deposits from Western Australia (Yilgarn craton) and Canada (Abitibi greenstone belt, Superior craton) using multiple isotopes of sulfur $\left(\Delta^{33} \mathrm{~S}, \quad \delta^{34} \mathrm{~S}\right)$ and iron isotopes $\left(\delta^{56} \mathrm{Fe}\right)$ has confirmed previous inferences that $\mathrm{S}$ is predominantly derived from crustal sources (Bekker et al., 2009; Hiebert et al., 2012). A sedimentary source was also indicated for some Archean $\mathrm{Ni}-\mathrm{Cu}$-(PGE) sulfide deposits in mafic-ultramafic intrusions of Botswana (Fiorentini et al., 2012) and Finland (Kannunaho et al., 2013). Mass-independent fractionation (MIF) of $\mathrm{S}$ isotopes is defined by non-zero $\Delta^{33} \mathrm{~S}$ values, where $\Delta^{33} \mathrm{~S} \approx \delta^{33} \mathrm{~S}-0.515 * \delta^{34} \mathrm{~S}$ (Hulston and Thode, 1965), and accompanies $\mathrm{SO}_{2}$ photolysis under ultraviolet radiation (Farquhar et al., 2001). MIF of S isotopes in Archean sulfides and sulfates has been attributed to the absence of an ozone shield in the anoxic Archean atmosphere (Farquhar et al., 2000; Pavlov and Kasting, 2002; Bekker et al., 2004). Multiple $\mathrm{S}$ isotope analysis thus allows differentiation between $\mathrm{S}$ with $\Delta^{33} \mathrm{~S} \neq 0 \%$ o that passed through the Archean atmosphere and magmatic $\mathrm{S}$ with $\Delta^{33} \mathrm{~S}=0 \%$. Bekker et al. (2009) observed both negative and positive $\Delta^{33} \mathrm{~S}$ values of Ni-bearing sulfide ore. For several deposits these values were similar to those of base-metal barren massive sulfides and sulfidic shales present in the footwall of the ore bodies. The sulfur in the Ni ores was interpreted by the authors to have likely been derived from the footwall sedimentary sulfides.

Fe isotope fractionation occurs during redox changes, fluid-mineral interactions and biological processes (e.g. Anbar and Rouxel, 2007; Johnson et al., 2008). While igneous and siliciclastic sedimentary rocks have near-zero $\delta^{56} \mathrm{Fe}$ values that cluster at $0.1 \%$ relative to the IRMM-14 standard, iron sulfides in Archean black shales, and volcanogenic massive sulfides of various ages systematically show negative iron isotope values as low as $-3.2 \%$ (Rouxel et al., 2005, unpubl. data). In contrast, banded iron formations generally yield more positive $\delta^{56} \mathrm{Fe}$ values up to $1.8 \%$, although distinct Fe isotope compositions are observed depending on Fe-bearing minerals, such as Fe-carbonate, magnetite or hematite (Johnson et al., 2008; Planavsky et al., 2012). Bekker et al. (2009) reported iron isotope composition of Archean komatiite-hosted Ni sulfides of the Yilgarn and Superior cratons to be close to 0\%, suggesting a predominantly magmatic source of iron in the sulfides.

To date, Ni stable isotope studies were mainly applied to cosmochemical processes (Moynier et al., 2007; Cook et al., 2008), with only few studies (Cameron et al., 2009; Tanimizu and Hirata, 2006) dealing with Ni isotope systematics of terrestrial rocks. Recently, Gueguen et al. (2013) estimated the bulk silicate Earth $\delta^{60 / 58} \mathrm{Ni}$ value to be around $+0.05 \pm$ $0.05 \%$ relative to SRM 986 standard. Recently reported $\delta^{60 / 58} \mathrm{Ni}$ values of komatiite-hosted Ni-rich sulfides from the Agnew-Wiluna greenstone belt in western Australia and the Abitibi 
greenstone belt in Canada vary from -0.10 to $-1.03 \pm 0.03 \%$, which indicates significant abiotic fractionations at high temperature in magmatic systems (Gueguen et al., 2013).

Sulfide mineral separates of selected samples were subjected to multiple $\mathrm{S}, \mathrm{Fe}$ and $\mathrm{Ni}$ isotope analyses. Analytical procedures are fully described in the appendix.

\section{Trojan Mine}

We separated sulfides from 11 samples from drillcore 35-1-20. Samples include sedimenthosted sulfide and sulfide from massive, net-textured and disseminated ore (Table 3). Sulfides show $\delta^{34} \mathrm{~S}$ values from -0.1 to $4.1 \%$ (Fig. 13A). All samples have a MIF signal with $\Delta^{33} \mathrm{~S}$ values ranging from 0.58 to $1.12 \%$. The metasedimentary sulfides have the highest $\delta^{34} \mathrm{~S}$ and the lowest $\Delta^{33} \mathrm{~S}$ values. The ore sulfides have relatively constant $\Delta^{33} \mathrm{~S}$ values irrespective of mineralization type. $\delta^{34} \mathrm{~S}$ and $\Delta^{33} \mathrm{~S}$ values of the metasedimentary sulfides and some ore sulfide samples show an apparent negative linear correlation. Iron isotope values of ore sulfides (Fig. 14) show a narrow range of $\delta^{56} \mathrm{Fe}$ values from -0.28 to $0.07 \%$ with the average of $-0.11 \%$, which is slightly lower than that for Eoarchean peridotites (Dauphas et al., 2009) and fertile upper-mantle derived from measurements of modern peridotites (Weyer and Ionov, 2007 ) and defined at $\sim 0.02 \%$. The metasedimentary sulfides have the lowest $\delta^{56} \mathrm{Fe}$ values ranging between -1.36 and $-1.52 \%$, which are within the range of $\delta^{56} \mathrm{Fe}$ values of Neoarchean sedimentary sulfides in metashales that have highly negative Fe isotope values (e.g., Rouxel et al., 2005).

Nickel isotope values of massive and net-textured ore samples from Trojan Mine display a restricted range of negative $\delta^{60 / 58} \mathrm{Ni}$ values from -0.23 to $-0.43 \%$ (Table 3 ) with the average value of $-0.38 \%$ within the range of, albeit less variable than, values for komatiite-hosted Nisulfides reported by Gueguen et al. (2013).

\section{Shangani Mine}

We separated sulfides from 9 samples of hand specimens and the drillcore 855/50W/2. Samples include sulfides from massive and net-textured ore from the Main Ore Body, disseminated sulfides, mainly present in carbonate veins in talcose serpentinite from the Main Ore Body, and pyrite nodules from carbonaceous shale associated with the Far West Ore Body (Table 3). The sedimentary pyrites in carbonaceous shale have the highest $\delta^{34} \mathrm{~S}(3.8$ to $5.1 \%$ ) and $\Delta^{33} \mathrm{~S}\left(1.8 \%\right.$ ) values (Fig. 13A), while $\delta^{56} \mathrm{Fe}$ values show systematic enrichment in light isotope and are as low as $-1.4 \%$ (Fig. 14). Disseminated sulfides in carbonate veins in talcose serpentinite as well as samples of net-textured ore have $\delta^{34} \mathrm{~S}$ values ranging from 0.8 
542 to $2.8 \%$, with the average $\Delta^{33} \mathrm{~S}$ value of $0.7 \%$, and $\delta^{56} \mathrm{Fe}$ values of -0.75 to $0.58 \%$. $\Delta^{33} \mathrm{~S}$

values of massive ore are within the range of mass-dependent fractionation of sulfur isotopes $\left(0.0 \pm 0.2 \%\right.$, Farquhar and Wing, 2003), and have $\delta^{34} \mathrm{~S}$ and $\delta^{56} \mathrm{Fe}$ values of 0.9 to $1.3 \%$ and 0.25 to $0.26 \%$, respectively. Only one $\mathrm{Ni}$ isotope analysis of the net-textured ore from Shangani Mine has been performed and it yielded a $\delta^{60 / 58} \mathrm{Ni}$ value of $-0.47 \%$, which is similar to that for ore samples from Trojan Mine.

\section{Gravity settling of sulfide melt vs. secondary hydrothermal processes}

According to Chimimba (1984), the main observations supporting a magmatic origin of the sulfides include the presence of intercumulus sulfides in matrix ore, the basal position of massive and matrix ore and the ordered sequence of massive, matrix and disseminated ore upwards from the footwall of the mineralized serpentinite bodies. However, the following observations argue against a simple gravity-settling model:

1) Although whole-rock Ni-content profiles in disseminated ore are gradual (Chimimba and Ncube, 1986), sudden changes in Ni-sulfide content can be present between the different ore zones and may testify to tectonic disturbance, as shear zones have been observed at the contact between the disseminated ore and the underlying more massive ore. In fact, when disseminated ore overlies a massive sulfide layer, a barren, 2-3 $\mathrm{m}$ wide zone is usually developed (Chimimba and Ncube, 1986).

2) The Ni-content in most of the ore bodies increases from the stratigraphic top to the bottom. The conspicuous exception to this rule is the Footwall No. 2 Ore Body (FW2OB) 
immediately north of the summit of Cardiff Hill (Fig. 3B). This ore body, which was mined to the $3^{\text {rd }}$ level before it became erratic, occurs in the hanging wall of an ultramafic lens. Its position has been explained by a synclinal fold that overturned the stratigraphy around the ore body (see Fig. 6), but the existence of this fold structure conflicts with an apparent lack of younging reversals to the east of the fold (Fig. 6). Consequently, the nickel sulfide enrichment of the FW2OB cannot be attributed to simple orthomagmatic processes.

3) The distribution of disseminated ore of the MOB is irregular and cuts through lithological contacts (Fig. 7A).

4) The deformation textures observed in schist horizons indicate high strain. Consequently, the current arrangement of lithologies bears little resemblance to the original stratigraphy and existing geometries cannot be unequivocally used to infer "depressions" responsible for the distribution of massive ore.

5) Fleet and Pan (1994) pointed out that $\mathrm{Ni}$ and $\mathrm{Cu}$ contents and their ratios in massive and disseminated ores at Trojan and Shangani mines are inconsistent with segregation of an immiscible sulfide liquid and may instead be related to subsolidus sulfide-silicate alteration reactions.

6) Although sulfides are recorded in interstitial position in matrix ore, a relation generally interpreted as primary magmatic, these sulfides are intergrown with metamorphic silicates (Fig. 9A). This means that such textures are not genuinely primary, but at least underwent modification during metamorphism.

7) Metasedimentary schists represent volcaniclastic deposits of intermediate to felsic composition that have been affected by synsedimentary hydrothermal processes resulting in base-metal enrichment as well as by metasomatic processes including silicification and albitization. They are more silicious and carbonaceous adjacent to mineralized ultramafic units in comparison with those associated with metabasalt. Silica is mobile during serpentinization of ultramafic rocks (e.g., Frost and Beard, 2007) and may have migrated from the ultramafic rocks into the adjacent sedimentary horizons upon shearing. Massive and nearmassive nickel sulfide ore bodies only occur in direct contact with chert and silicified, carbonaceous metasedimentary schist enriched in sulfide. The content of sulfide and carbonaceous matter are commonly correlated in organic matter-rich shales (e.g., Morse and Berner, 1995), which might explain why economic mineralization in ultramafic bodies is present only in the vicinity of highly sulfidic and carbonaceous shales. This could indicate that ore bodies developed only in the vicinity of black sulfidic shales due to crustal assimilation. Alternatively, it is conceivable that sulfur, derived from the breakdown reaction 
of pyrite into pyrrhotite in carbonaceous shale at lower-amphibolite facies conditions (Craig and Vokes, 1993; Tomkins, 2010), may have entered the ultramafic rocks with hydrothermal fluids channeled along shear zones bounding the ultramafic bodies. This process would also require Ni liberation from the ultramafic rocks during serpentinization and their subsequent migration into ore horizons.

\section{Structural vs. stratigraphic controls on ore body geometry}

The complicated intercalation of basalt, ultramafic rocks and metasedimentary units is not an original volcano-sedimentary stratigraphy. Many lithological contacts in the area are strongly sheared. In addition, the siliceous schists are not primary chemical sedimentary deposits but strongly silicified and sheared metasedimentary rocks.

An important indication that structural-metamorphic processes played a role in the mobilization of the nickel ore deposit at Trojan Mine is the linear nature of the ore bodies and lensoidal geometry of ultramafic host rocks parallel to the $\mathrm{S}_{0} / \mathrm{S}_{1}$ intersection lineation (Fig. 5D). A similar relationship exists at Shangani Mine (Dirks and Sithole, 1996) and has also been described from other deposits in Western Australia (e.g., Barrett et al., 1977, Gresham and Loftus-Hills, 1981). To explain this alignment, it has been suggested that the linear nature of ore bodies reflects the shape of volcanic flow channels and that massive sulfide deposits are responsible for strength heterogeneity in the crust localizing strain (e.g., Gresham and Loftus-Hills, 1981). Although such linear flow channels may have existed, it appears highly unlikely that they are, almost as a rule, parallel to the orientation of peak-metamorphic linear deformation features of regional significance. Regarding Trojan Mine, this means that the intersection lineation, which is identical in a large area around the mine, cannot possibly be dictated by relatively small linear bodies that occur within the sequence, and it is much more likely that the linear nature of the ore bodies and the host ultramafic rocks resulted from regional tectonics. An alternative suggestion that ore bodies may have rotated to be parallel with the regional strain (e.g., Lacroix and Darling, 1991) is also unlikely. First, to attain the near perfect alignment, very high penetrative strain is required, yet not recorded. Second, high strain would align the ore bodies with the direction of maximum elongation $\left(\mathrm{L}_{1}\right)$, which in the Trojan Mine area is plunging shallowly to the SW (Fig. 5B), yet the ore bodies dip steeply NW parallel to the $\mathrm{S}_{0}-\mathrm{S}_{1}$ intersection lineation (Fig. 5C). For these reasons it is compelling that the linear nature of the ore bodies and their host rocks has a structural-metamorphic origin. 


\section{Hydrothermal control on sulfide mineralization at Trojan Mine}

The area around Trojan Mine has been strongly deformed during several phases of deformation. Extensive metamorphic reworking of the ultramafic rocks has likely taken place. It is possible that reworking was associated with remobilization of $\mathrm{Ni}$ and $\mathrm{S}$, resulting in a hydrothermal control over ore formation. Faults represent zones of high permeability and act as conduits for hydrothermal fluids. There is abundant evidence for hydrothermal activity within the metasedimentary units that were preferentially affected by shearing. Deformation increased permeability of massive ultramafic bodies and may have allowed a pervasive hydrothermal fluid circulation, intense water-rock interaction and enhanced serpentinization. In contrast to $\mathrm{Cr}$, $\mathrm{Ni}$ in ultramafic rocks can be mobile during hydrothermal alteration, such as silicification (Hofmann and Harris, 2008), and is liberated from olivine during serpentinization (e.g., Eckstrand, 1975; Donaldson, 1981). Sulfur could have been sourced from pyrite breakdown in sulfidic shales, entered altered volcanic rocks along shear zones and preferentially scavenged siderophile elements, such as $\mathrm{Ni}$ and Fe. Ore shoots developed along structural features controlled by thrusting of the greenstone sequences, coaxial to the $\sigma_{3}$ direction characterized by a pervasive regional mineral lineation. During subsequent deformation and metamorphic events related to gneiss doming and strike-slip shearing, ore bodies were rotated and reoriented. Locally, massive sulfide ore bodies were extensively reworked, resulting in injection veins into footwall rocks and brecciated ores.

The problem with a hydrothermal-metamorphic origin for nickel sulfide mineralization is the role of primary sulfides in ultramafic rocks. Were primary disseminated sulfides present in the ultramafic rocks and were subsequently upgraded and remobilized by hydrothermal and metamorphic processes? Did disseminated sulfides form by secondary, hydrothermal and metamorphic processes? Did a combination of these processes take place? Multiple sulfur and iron isotope data help to differentiate between igneous and sedimentary sulfur sources as well as low- and high-temperature processes (Bekker et al., 2009). We therefore further explore below the question whether these proxies, in combination with $\mathrm{Ni}$ isotopes, can help to differentiate between a hydrothermal-metamorphic and orthomagmatic control on Ni sulfide mineralization.

\section{Constraints from multiple $\mathrm{S}, \mathrm{Fe}$ and $\mathrm{Ni}$ isotope analyses}

We consider that the distinct MIF signal of samples from Trojan Mine (Fig. 13) suggests derivation of sulfur from crustal, sedimentary sources. Positive $\Delta^{33} \mathrm{~S}$ values suggest that sulfur was most likely derived from disseminated pyrite in shale, which commonly have highly 
positive $\Delta^{33} \mathrm{~S}$ values in Neoarchean sedimentary successions (e.g., Farquhar and Wing, 2005; Ono et al., 2009). The sulfides in shales at Trojan Mine are predominantly secondary in origin, and were formed by sulfur remobilization. Interestingly, they have lower $\Delta^{33} \mathrm{~S}$ values compared to the ore sulfides, which may indicate that secondary sulfide in the shale was derived from a mixture of sources, possibly also including sulfur with negative and even zero $\Delta^{33} \mathrm{~S}$ values.

MDF of S isotopes of massive ore from Shangani Mine most likely suggests a magmatic source of the sulfur as sedimentary to early diagenetic sulfides in associated metashales show distinctly positive $\Delta^{33} \mathrm{~S}$ values. Alternatively, it might suggest crustal assimilation and subsequent sulfur isotope homogenization in a large crustally-derived sulfur reservoir, removing mass-independent fractionation of sulfur isotopes unique to a particular lithology (Fiorentini et al., 2012). In contrast, the $\mathrm{S}$ isotope values of sulfides in veins in talcose serpentinite and in net-textured ore appear to lie on a mixing line between magmatic and sedimentary end-members, suggesting a contribution of both.

The small range of iron isotope values in ore sulfides from Trojan Mine suggests that, in contrast to sulfur, most of iron could have been derived from magmatic sources (cf. Hiebert et al., 2013). As recently discussed by Craddock and Dauphas (2011), ultramafic and mafic rocks have an iron isotopic composition similar to that in chondrites $(-0.01 \pm 0.01 \%)$ and different from that in more evolved and differentiated rocks. Hence, our results suggest Fe isotope fractionation of less than $0.2 \%$ between Ni-sulfides and silicates by high-temperature magmatic processes, which is consistent with previous studies (Schuessler et al., 2007). Fe isotope data for secondary sulfides in the metashales and metagraywackes cluster at $-1.45 \%$ o (Fig. 14) suggesting that they were derived from either sedimentary or hydrothermal sulfides remobilized on the scale of their hosting units during deformation and metamorphism. Although negative $\delta^{56} \mathrm{Fe}$ values in sedimentary pyrite have been previously interpreted as reflecting microbial Fe reduction (e.g., Archer and Vance, 2006; Severmann et al., 2008), it is now widely accepted that abiotic Fe-sulfide precipitation in aqueous systems, both in sedimentary and hydrothermal settings, produces Fe isotope fractionations of up to $\sim 1.5 \%$, with light $\mathrm{Fe}$ isotopes being enriched in Fe-sulfide relative to $\mathrm{Fe}^{2+}{ }_{\text {aq }}$ (Butler et al., 2005; Polyakov et al., 2007; Rouxel et al., 2008; Bennett et al., 2009; Guilbaud et al., 2011).

In contrast, the negative $\mathrm{Fe}$ isotope values as low as $-1.4 \%$ for pyrite nodules from shales in the Shangani Mine area are likely to reflect low-temperature fractionation processes during sulfide formation during early diagenesis. Although hydrothermal fluid circulation may also 
711 produce isotopically light pyrite (Rouxel et al., 2008), the distinctly positive $\Delta^{33} \mathrm{~S}$ values in these pyrites suggest rather a sedimentary origin.

In contrast to slightly negative $\delta^{56} \mathrm{Fe}$ values of massive ore from Trojan Mine, massive ore at Shangani Mine has positive $\delta^{56} \mathrm{Fe}$ values of around $0.25 \%$. Although we currently lack experimental constraints, such difference can be explained by the different mineralogy of the ore deposits. The Shangani Mine ore samples investigated in this study are essentially composed of chalcopyrite, while only pyrrhotite-pentlandite assemblages were analyzed from Trojan Mine. As discussed by Rouxel et al. (2008), it is likely that the equilibrium Fe isotope fractionation between chalcopyrite and $\mathrm{Fe}^{2+}$ in either aqueous or melt phase is slightly positive, yielding more positive $\delta^{56} \mathrm{Fe}$ values for chalcopyrite. Iron isotope values of disseminated sulfides in serpentinite show a narrow range of $\delta^{56} \mathrm{Fe}$ values between -0.10 and $0.04 \%$ with the exception of two outliers with $-0.75 \%$ and $0.58 \%$ values. The narrow range can be explained by iron isotope fractionation between sulfides and silicates in a magmatic system, while the two outliers might reflect composition of sulfide xenomelt formed by assimilation of crustal lithologies that was not completely homogenized with the magma. However, there is no correlation between the values of MIF of S isotopes and Fe isotope values as would be expected if both Fe and $\mathrm{S}$ were derived from crustal (sedimentary) source. In modern seafloor-basalt weathering environments, hydrothermal alteration may release iron with negative iron isotope values, leaving altered rocks enriched in heavy isotopes (Rouxel et al., 2003). Hence, Fe mobility during hydrothermal alteration might be responsible for these two outliers having both negative and positive $\delta^{56} \mathrm{Fe}$ values. In addition, there is also negative iron isotope fractionation during precipitation of sulfides from cooling hydrothermal fluids (e.g., Rouxel et al., 2005). These two processes can explain the highly negative iron isotope value in the talcose serpentinite. The positive iron isotope value in the net-textured serpentinite might reflect final stages in Rayleigh distillation by either sulfide precipitation from hydrothermal fluids or iron leaching from ultramafic rocks. Resolution between these two alternatives requires further detailed study, which is beyond the scope of this paper.

Whole-rock Ni concentrations in sedimentary rocks are typically much lower than in mantle-derived ultramafic rocks, which are the likely source for $\mathrm{Ni}$ in magmatic sulfides. $\mathrm{Ni}$ isotope composition of pyrrhotite-pentlandite ore revealed systematic enrichment in light isotopes to values as low as $-0.47 \%$ relative to their ultramafic magma source for which we assumed Ni isotopic composition to be close to the Bulk Silicate Earth value of $0.05 \pm 0.05 \%$ o (Gueguen et al., 2013). $\delta^{60 / 58} \mathrm{Ni}$ values for both the Trojan and Shangani mines Ni ores form a narrow range from -0.47 to $-0.28 \%$, which clearly indicates a unique mechanism responsible 
745 for this light isotope enrichment. For instance, for the Trojan mine deposit, the average

$\delta^{60 / 58} \mathrm{Ni}$ value is $-0.38 \%$ o $(\mathrm{n}=5)$, which is consistent with the negative fractionation of $-0.3 \%$ o between metal and silicate phases obtained by Huh et al. (2009). These authors suggested that $\mathrm{Ni}$ isotope fractionation between these two phases was due to nucleation, growth, and annealing mechanisms in the experimental setup, leading to significant fractionation of $\mathrm{Ni}$ isotopes at high temperature. These negative values contrast with the strictly positive $\mathrm{Ni}$ isotope composition measured in modern marine metallifereous sediments, such as ferromanganese crusts and manganese nodules, which varies from $+0.36 \%$ to $+1.80 \%$ o (Gueguen et al., 2013), arguing further against a sedimentary source of $\mathrm{Ni}$ in komatiites, in contrast to S. Although at this stage it is difficult to establish the exact cause of Ni isotope fractionation in magmatic sulfides due to limited experimental and theoretical studies of this new isotopic system, the data provide interesting information on $\mathrm{Ni}$ isotope behavior under high-temperature conditions. Specifically, they suggest that there is significant fractionation of $\mathrm{Ni}$ isotopes, even higher than that for $\mathrm{Fe}$ isotopes, and that Ni-sulfide (or sulfide melt) formation produces systematic enrichment in light Ni isotopes with respect to the composition of silicate melt.

\section{Can multiple $S$ and Fe isotope data constrain the origin of Ni-sulfide mineralization at Trojan} and Shangani mines?

The presence of mass-independent fractionation of multiple sulfur isotopes in Archean komatiite-hosted Ni-sulfide deposits implies that the sulfur was previously processed through the atmosphere and then accumulated on the ocean floor prior to incorporation into the ultramafic magmas. Several Archean komatiite-hosted Ni-sulfide deposits show massindependent sulfur isotope fractionation, suggesting incorporation of sulfur from seafloor hydrothermal sulfide accumulations or sulfidic shales (Bekker et al., 2009; Fiorentini et al., 2012; Hiebert et al., 2013; Kannunaho et al., 2013). Nickel-sulfides of the Kambalda deposit show only mass-dependent fractionation of sulfur isotopes, which has been explained by either a magmatic sulfur source or assimilation of multiple crustal sulfur sources, mixing with mantle-derived sulfur and sulfur homogenization removing a mass-independent signal (Bekker et al., 2009). On the scale of a single ore body, assimilation of sedimentary or seafloor, hydrothermal sulfides by thermal erosion in a lava channel and mixing with magmatic sulfur in the turbulent flow, followed by gravitational settling of sulfides upon lava ponding should lead to a relatively homogeneous isotopic composition of sulfides. In contrast, sulfidization with sulfur derived from sedimentary sources via hydrothermal fluid circulation 
should result in a more heterogeneous sulfur isotope composition of $\mathrm{Ni}$ sulfides with sulfides in and close to shear zones (fluid conduits) and sedimentary units having values reflecting a post-magmatic source of S derived from the hosting sedimentary succession. Similarly, iron and nickel isotope values can be used to test between the orthomagmatic and hydrothermal models. If Ni-sulfides formed in an isotopic equilibrium with silicate melt in a hightemperature magmatic system, iron and nickel isotope values of unaltered olivine and sulfide should reflect limited fractionation under high-temperature conditions and the mantle source of metals. Alternatively, if hydrothermal processes led to formation of Ni sulfides, they will not be in high-temperature equilibrium with adjacent silicates and will likely show a larger range of iron and nickel isotope values depending on pathways and kinetics of sulfide precipitation (Rouxel et al., 2008) as well as redox transformations and low-temperature fractionations among minerals and with fluids.

Sulfides in metasedimentary rocks at Trojan and Shangani mines show distinctly positive $\Delta^{33} \mathrm{~S}$ values. Early diagenetic pyrite nodules in ca. $2.7 \mathrm{Ga}$ organic matter-rich shales from different greenstone belts in Zimbabwe (Bekker et al., 2008) carry predominantly negative $\Delta^{33} \mathrm{~S}$ values, likely reflecting seawater sulfate reduction in sediments during diagenesis or in the water column. They occur in a matrix of shale with disseminated pyrite having highly positive $\Delta^{33} \mathrm{~S}$ values, likely inherited from photochemically-produced, reduced S species such as elemental S (Farquhar and Wing, 2003, 2005; Ono et al., 2009). Sulfides in metasedimentary rocks at Trojan Mine occur in secondary veinlets, while those at Shangani Mine are strongly recrystallized. However, their positive $\Delta^{33} \mathrm{~S}$ values strongly suggest that the precursor sulfides in the sediment were predominantly derived from photochemicallyprocessed elemental sulfur. At both mines, all ore samples that show mass-independent fractionation have positive $\Delta^{33} \mathrm{~S}$ values, again suggesting that the bulk of the sulfur was derived from disseminated pyrite that did not form by reduction of seawater sulfate. This is unlike some other Neoarchean komatiite-hosted Ni-sulfide deposits that have negative $\Delta^{33} \mathrm{~S}$ values indicating that they may have assimilated sulfur from distal, barren volcanogenic massive sulfides (e.g., Bekker et al., 2009). The latter sulfides formed by seawater circulation through hydrothermal systems and seawater sulfate reduction and commonly carry near to zero or small negative $\Delta^{33} \mathrm{~S}$ values (Farquhar and Wing, 2005; Ueno et al., 2008; Bekker et al., 2009; Jamieson et al., 2013).

At Shangani Mine, massive ore shows mass-dependent fractionation of sulfur isotopes, which is most easily attributed to a predominantly magmatic sulfur source. Alternatively, assimilation and subsequent sulfur isotope homogenization in a large crustally-derived sulfur 
813 reservoir, erasing mass-independent fractionation of sulfur isotopes might be responsible for this signal. Adding support to the former interpretation, disseminated sulfides in talcose serpentinite record evidence for mass-independent fractionation and plot along a mixing line between sedimentary and massive sulfides (Fig. 13B). It is plausible that the sulfur in the disseminated ore may represent a mixture of hydrothermally-remobilized magmatic and sedimentary sulfur. Net-textured ore differs from disseminated ore only in slightly lower $\delta^{34} \mathrm{~S}$ values, possibly due to mass-dependent equilibrium fractionation among sulfide minerals in the ore. Iron isotope values of Ni-sulfides show a narrow range consistent with their predominantly magmatic iron source with the exception of two samples from talcose serpentinite that were likely strongly affected by Fe remobilization during hydrothermal activity.

At Trojan Mine, ore sulfides show a restricted range of positive $\Delta^{33} \mathrm{~S}$ values, inconsistent with a hydrothermal control over sulfide mineralization. Sulfides in metasediments, albeit secondary in origin, have slightly lower but still positive $\Delta^{33} \mathrm{~S}$ values, which could indicate that most, if not all, of the sulfur in the ore body was derived from a sedimentary rather than a magmatic source. Net-textured and disseminated ores and metasedimentary rocks lie on a distinct trend on the $\Delta^{33} \mathrm{~S}$ vs. $\delta^{34} \mathrm{~S}$ diagram (see Fig. 13A), indicating that during komatiite emplacement and assimilation of crustal sulfur to reach sulfur saturation sulfur isotope systematics of crustal source was inherited with little modification (cf. Hiebert et al., 2013). However, subsequent hydrothermal processes may have led to exchange between adjacent metasediments and Ni-sulfide in komatiite. As a result of this exchange, S, Ni and possibly other chalcophile elements (e.g., $\mathrm{Cu}$ ) were added to the metasediments and, in other cases, sedimentary sulfur was introduced to komatiite. Iron isotope values of Ni-sulfides from Trojan Mine have a narrow range suggesting that the iron inventory in komatiite is predominantly of mantle derivation. and ore bodies have been reoriented, inconsistent with the previously proposed model of 
simple, orthomagmatic nickel-sulfide mineralization. We have however shown that the combination of multiple $\mathrm{S}, \mathrm{Fe}$, and $\mathrm{Ni}$ isotope data provides a 'see-through' proxy to test whether magmatic or metamorphic-hydrothermal processes played a major role in ore genesis. For the Zimbabwean Ni-sulfide deposits described herein, which are generally of low-grade $(0.5-0.6 \% \mathrm{Ni})$, a magmatic origin with subsequent hydrothermal reworking is indicated. While massive nickel-sulfides at the Shangani Mine deposit could have formed via high-temperature magmatic processes without the addition of sedimentary sulfur, assimilation of crustal sulfur was critical for the origin of net-textured and disseminated ore mineralization at Trojan Mine. The net-textured and disseminated ore mineralization at Shangani Mine could have been formed by post-magmatic hydrothermal processes with sulfur derived from a mixture of magmatic and sedimentary sources. This study indicates that the post-magmatic geological history of komatiite-hosted nickel-sulfide deposits should not be discounted in genetic models for mineralization and that metamorphic and hydrothermal processes could be a controlling factor in the formation and upgrading of low-grade nickel-sulfide deposits in terrains strongly affected by tectono-metamorphic overprints.

\section{Acknowledgements}

AH acknowledges support by NAI International Collaboration Grant and NRF grant FA2005040400027. AB participation was supported by NSF grant EAR 05-45484, NAI award No. NNA04CC09A, and NSERC Discovery grant. Research by PD was supported by Stichting Schürmannfonds grants 1996-2003/13, and by extensive support by AngloAmerican PLC in allowing access to Zimbabwean Ni-deposits. Support for OR and BG was provided by Europole Mer, ISOMAR and NSF-EAR grant. We thank Charles Makuni for access to drill core, the Department of Geology, University of Zimbabwe for logistical support and Emmanuel Ponzevera, Yoan Germain, and Celine Liorzou (PSO, Brest) for analytical support. Constructive comments by journal editor Bernd Lehmann, Boswell Wing and two additional reviewers are gratefully acknowledged.

\section{References}

Anbar AD, Rouxel O (2007) Metal stable isotopes in paleoceanography. Annu Rev Earth Planet Sci 35:717-746

Archer C, Vance D (2006) Coupled Fe and S isotope evidence for Archean microbial Fe (III) and sulfate reduction. Geology 34:153-156 
Arndt NT, Lesher CM, Czamanske GK (2005) Mantle-derived magmas and magmatic Ni-Cu(PGE) deposits. Econ Geol, 100th Anniv Vol:5-23

Baglow N (1986) The Epoch nickel deposit, Zimbabwe. In: Anhaeusser CR, Maske S (eds) Mineral deposits of Southern Africa. Geol Soc S Afr, pp 255-262

Baglow N (1992) Bindura, Geological Survey of Zimbabwe, 1: 100,000 geological map sheet

Barnes SJ (2006) Komatiite-hosted nickel sulfide deposits: geology, geochemistry, and genesis. In: Barnes SJ (ed) Nickel deposits of the Yilgarn Craton. Soc Econ Geol Spec Publ 13, p. 51-97.

Barrett FM, Binns RA, Groves DI, Marston RJ, McQueen KG (1977) Structural history and metamorphic modification of Archean volcanic-type nickel deposits, Yilgarn Block, Western Australia. Econ Geol 72:1195-1223

Barrie, CT (1999) Komatiite flows of the Kidd Creek footwall, Abitibi Subprovince, Canada. Econ Geol Monographs 10:143-161

Bau M (1996) Controls on the fractionation of isovalent trace elements in magmatic and aqueous systems: evidence from $\mathrm{Y} / \mathrm{Ho}, \mathrm{Zr} / \mathrm{Hf}$, and lanthanide tetrad effect. Contrib Mineral Petrol 123:323-333

Bavinton OA (1981) The nature of sulfidic sediments at Kambalda and their broad relationships with associated ultramafic rocks and nickel ores. Econ Geol 76:1606-1628

Bekker A, Barley ME, Fiorentini ML, Rouxel OJ, Rumble D, Beresford SW (2009) Atmospheric Sulfur in Archean Komatiite-Hosted Nickel Deposits. Science 326:10861089

Bekker A, Hofmann A, Rumble D, Rouxel O (2008) Sulfidic organic-rich shales in the Archean low-sulfate ocean: Evidence for transient oxygenated conditions, enhanced volcanism, or low sedimentation rates? Geochim Cosmochim Acta 72, Supplement 1:A69

Bekker A, Holland HD, Wang PL, Rumble III D, Stein HJ, Hannah JL, Coetzee LL, Beukes NJ (2004) Dating the rise of atmospheric oxygen. Nature 427:117-120

Bennett SA, Rouxel OJ, Schmidt K, Garbe-Schönberg D, Statham PJ, German CR (2009) Iron isotope fractionation in a buoyant hydrothermal plume from the Mid-Atlantic Ridge at $5^{\circ} \mathrm{S}$. Geochim Cosmochim Acta 73:5619-5634

Bolhar R, Van Kranendonk MJ, Kamber BS (2005) A trace element study of siderite-jasper banded iron formation in the 3.45 Ga Warrawoona Group, Pilbara Craton-formation from hydrothermal fluids and shallow seawater. Precambrian Res 137:93-114

Butler IB, Archer C, Vance D, Oldroyd A, Rickar, D (2005) Fe isotope fractionation on FeS formation in ambient aqueous solution. Earth Planet Sci Lett 236:430-442 
914 Cameron V, Vance D, Archer C, House CH (2009) A biomarker based on the stable isotopes

Cas RAF, Beresford SW (2001) Field characteristics and erosional processes associated with komatiitic lavas: implications for flow behavior. Can Mineral 39:505-524

Chimimba LR (1984) Geology and mineralization at Trojan nickel mine, Zimbabwe. In: Buchanan DL, Jones MJ (eds) Sulfide deposits in mafic and ultramafic rocks: Institution of Mining and Metallurgy, pp 147-155

Chimimba LR, Ncube SMN (1986) Nickel sulfide mineralisation at Trojan mine, Zimbabwe. In: Anhaeusser CR, Maske S (eds) Mineral deposits of Southern Africa: Geol Soc S Afr, pp 249-253

Chimimba LR (1987) The geology and mineralisation of Trojan nickel mine, Bindura area, Zimbabwe: PhD thesis, University of Zimbabwe, Harare

Condie KC, Wronkiewicz DJ (1990) The Cr/Th ratio in Precambrian pelites from the Kaapvaal Craton as an index of craton evolution. Earth Planet Sci Lett 97:256-267

Cook DL, Clayton RN, Wadhwa M, Janney PE, Davis AM (2008) Nickel isotopic anomalies in troilite from iron meteorites. Geophys Res Lett 35:L01203

Cowden A (1988) Emplacement of komatiite lava flows and associated nickel sulfides at Kambalda, Western Australia. Econ Geol 83:436-442

Cowden A, Roberts DE (1990) Komatiite hosted nickel sulfide deposits, Kambalda. In: Hughes FE (ed) Geology of the Mineral Deposits of Australia and Papua New Guinea: Australasian Institution of Mining and Metallurgy, Melbourne, Australia, pp 567-581

Craddock PR, Dauphas N (2011) Iron and carbon isotope evidence for microbial iron respiration throughout the Archean. Earth Planet Sci Lett 303:121-132

Craig JR, Vokes FM (1993) The metamorphism of pyrite and pyritic ores: an overview. Mineral Mag 57:3-18

Dauphas N, Rouxel O (2006) Mass spectrometry and natural variations of iron isotopes. Mass Spectrom Rev 25:515-550

Dauphas N, Craddock PR, Asimow PD, Bennett VC, Nutman AP, Ohnenstetter D (2009) Iron isotopes may reveal the redox conditions of mantle melting from Archean to Present. Earth Planet Sci Lett 288:255-267

Dirks, PHGM, Sithole, TA (1996) Report on structural controls on nickel mineralisation at Shangani Mine, Zimbabwe. Consultant report, Anglo American Corporation Zimbabwe Pvt. Ltd. 
Dirks PHGM, Jelsma HA (1998) Silicic layer-parallel shear zones in a Zimbabwean greenstone sequence; horizontal accretion preceding doming. Gondwana Res 1:177-194

Donaldson MJ (1981) Redistribution of ore elements during serpentinization and talccarbonate alteration of some Archean dunites, Western Australia. Econ Geol 76:16981713

Eckstrand OR (1975) The Dumont serpentinite: a model for control of opaque nickeliferous mineral assemblages by alteration reactions in ultramafic rocks. Econ Geol 70:183-201

Farquhar J, Wing BA, (2005) The terrestrial record of stable sulfur isotopes: a review of the implications for evolution of Earth's sulfur cycle. In: McDonald I, Boyce AJ, Butler IB, Herrington RJ, Polya DA (eds) Mineral Deposits and Earth Evolution. Geol Soc London Spec Publ 248:167-177

Farquhar J, Bao H, Thiemens M (2000) Atmospheric influence of Earth's earliest sulfur cycle. Science 289:756-758

Farquhar J, Savarino J, Airieau S, Thiemens MH (2001) Observation of wavelength-sensitive mass-independent sulfur isotope effects during SO2 photolysis: Implications for the early atmosphere. J Geophys Res 106:1-11

Fiorentini ML, Bekker A, Rouxel O, Wing BA, Maier W, Rumble D (2012) Multiple sulfur and iron isotope composition of magmatic $\mathrm{Ni}-\mathrm{Cu}-(\mathrm{PGE})$ sulfide mineralization from Eastern Botswana. Econ Geol 107:105-116

Fleet ME, Pan Y (1994) Fractional crystallization of anhydrous sulfide liquid in the system $\mathrm{Fe}-\mathrm{Ni}-\mathrm{Cu}-\mathrm{S}$, with application to magmatic sulfide deposits. Geochim Cosmochim Acta 58: $3369-3377$

Frost BR, Beard JS (2007) On silica activity and serpentinization. J Petrol 48:1351-1368

Gueguen B, Rouxel O, Ponzevera E, Bekker A, Fouquet Y (2013) Nickel isotope variations in terrestrial silicate rocks and geological reference materials measured by MC-ICP-MS. Geostand Geoanal Res doi:10.1111/j.1751-908X.2013.00209.x.

Gresham JJ, Loftus-Hills GD (1981) The geology of the Kambalda nickel field, western Australia. Econ Geol 76:1373-1416

Groves DI, Korkiakoski EA, McNaughton NJ, Lesher CM, Cowden A (1986) Thermal erosion by komatiites at Kambalda, Western Australia, and the genesis of nickel ores. Nature 319:136-139

Grguric BA, Rosengren NM, Fletcher CM, Hronsky JM (2006) Type 2 deposits: Geology, mineralogy and processing of the Mt. Keith and Yakabindie orebodies, Western Australia. 
In: Barnes SJ (ed) Nickel deposits of the Yilgarn Craton. Soc Econ Geol Spec Publ 13:119-138

Guilbaud R, Butler IB. Ellam RM (2011) Abiotic pyrite formation produces a large Fe isotope fractionation. Science 332:1548-1551

Harrison NM (1969) The geology of the country around Ford Rixon and Shangani. Rhod Geol Surv Bull 61

Hiebert RS, Bekker A, Houle MG, Lesher CM, Wing BA (2012) Multiple sulphur isotopes as a method to evaluate sulphur sources and a potential exploration tool in the komatiite associated nickel-copper-(Platinum Group Elements) Hart Deposit, Shaw Dome, Abitibi Greenstone Belt, Ontario. Ontario Geological Survey, Open File Report 6280:45-1-45-9

Hiebert R, Bekker A, Wing BA, Rouxel OJ (2013) The role of paragneiss assimilation in the origin of the Voisey's Bay Ni-Cu sulfide deposit, Labrador: multiple $\mathrm{S}$ and Fe isotope evidence. Econ Geol, in press

Hill RET, Barnes SJ, Gole MJ, Dowling SE (1995) The volcanology of komatiites as deduced from field relationships in the Norseman-Wiluna greenstone belt, Western Australia. Lithos 34:158-188

Hofmann A, Harris C (2008) Stratiform alteration zones in the Barberton greenstone belt: a window into subseafloor processes 3.5-3.3 Ga ago. Chem Geol 257:224-242

Hofmann A, Dirks PHGM, Jelsma HA (2002) Late Archaean clastic sediments (Shamvaian Group) of the Zimbabwe craton: first observations from the Bindura-Shamva greenstone belt. Can J Earth Sci 39:1689-1708

Hofmann A, Dirks PHGM, Jelsma HA, Matura N (2003) A tectonic origin for ironstone horizons in the Zimbabwe craton and their significance for greenstone belt geology. J Geol Soc London 160:83-97

Hofmann A, Bekker A, Rouxel O, Rumble D, Master S (2009) Multiple sulphur and iron isotope composition of detrital pyrite in Archaean sedimentary rocks: a new tool for provenance analysis. Earth Planet Sci Lett 286:436-445

Hopwood T (1981) The significance of pyritic black shales in the genesis of Archean nickel sulfide deposits. In: Wolf KH (ed) Handbook of strata-bound and stratiform ore deposits, 9. Elsevier, Amsterdam, pp 411-468

Hronsky JMA, Schodde RC (2006) Nickel exploration history of the Yilgarn craton: from the nickel boom to today. In: Barnes SJ (ed) Nickel deposits of the Yilgarn Craton. Soc Econ Geol Spec Publ 13:1-11 
1013

${ }_{2}^{1} 1014$

${ }_{4}^{3} 1015$

51016

71017

8

91018

10

111019

12

131020

14
15

161022

17

181023

19

201024

21

221025

23

241026

25
26

271028

28

291029

30

311030

32

331031

34
35
3632

36
37

381034

39

401035

41

421036

43

$44^{1037}$

${ }_{46}^{45} 1038$

481039

491040

50

511041

52

531042

54

551043

561044

581045

59

60

61

62

63

64

65

Hu GX, Rumble D, Wang PL (2003) An ultraviolet laser microprobe for the in situ analysis of multisulfur isotopes and its use in measuring Archean sulfur isotope mass-independent anomalies. Geochim Cosmochim Acta 67:3101-3118

Hulston JR, Thode HG (1965) Variations in the S33, S34, and S36 contents of meteorites and their relation to chemical and nuclear effects. J Geophys Res 70:3475-3484

Huh MC, Lazar C, Young ED, Manning CE (2009) High temperature fractionation of Ni stable isotopes between metal and silicates: constraints from experimental study at $800^{\circ} \mathrm{C}$ and 10kbar. 2009AGUFM.V11C1974H

Huppert HE, Sparks RSJ, Turner JS, Arndt NT (1984) Emplacement and cooling of komatiite lavas. Nature 309:19-22

Jamieson JW, Wing BA, Farquhar J, Hannington MD (2013) Neoarchaean seawater sulphate concentrations from sulphur isotopes in massive sulphide ore. Nature Geosci $6: 61-64$

Jelsma HA (1993) Granites and greenstones in northern Zimbabwe, tectono-thermal evolution and source regions: $\mathrm{PhD}$ thesis, Free University of Amsterdam

Jelsma HA, Dirks PHGM (2000) Tectonic evolution of a greenstone sequence in northern Zimbabwe: sequential early stacking and pluton diapirism. Tectonics 19:135-152

Jelsma HA, Vinyu ML, Valbracht PJ, Davies GR, Wijbrans JR, Verdurmen EAT (1996) Constraints on Archaean crustal evolution of the Zimbabwe craton: a U-Pb zircon, $\mathrm{Sm}-\mathrm{Nd}$ and $\mathrm{Pb}-\mathrm{Pb}$ whole-rock isotope study. Contrib Mineral Petrol 124:55-70

Johnson CM, Beard BL, Roden EE (2008) The Iron Isotope Fingerprints of Redox and Biogeochemical Cycling in Modern and Ancient Earth. Annu Rev Earth Planet Sci $36: 457-493$

Konnunaho JP, Hanski EJ, Bekker A, Halkoaho TAA, Hiebert RS, Wing BA, Karinen TT (2013) The Archean komatiite-hosted, PGE-bearing Ni-Cu sulfide deposit at Vaara, eastern Finland. Minera Deposita, in press.

Keays RR (1995) The role of komatiitic and picritic magmatism and S-saturation in the formation of ore deposits. Lithos 34:1-18

Killick AM (1986) The Damba sulfide nickel deposits, Zimbabwe. In: Anhaeusser CR, Maske S (eds) Mineral deposits of Southern Africa. Geol Soc S Afr, pp 263-273

Lacroix S, Darling R (1991) Tectonized Cu-Ni deposits of the Aulneau-Redcliff area, Central Labrador Trough, Quebec. Econ Geol 56:718-739

Lesher CM (1989) Komatiite-associated nickel sulfide deposits. Rev Econ Geol 4:45-101 
Lesher CM, Burnham OM (2001) Multicomponent elemental and isotopic mixing in $\mathrm{Ni}-\mathrm{Cu}-$ (PGE) ores at Kambalda, Western Australia. Can Mineral 39:421-446

Lesher CM, Keays RR (2002) Komatiite-associated Ni-Cu-(PGE) deposits: Mineralogy, geochemistry, and genesis. Canadian Institute of Mining, Metallurgy and Petroleum Special Volume 54:579-617

Lesher CM, Arndt NT, Groves DI (1984) Genesis of komatiite-associated nickel sulfide deposits at Kambablda, Western Australia: a distal volcanic model. In: Buchanan DL, Jones MJ (eds) Sulfide deposits in mafic and ultramafic rocks: Institution of Mining and Metallurgy, London, pp 70-80

Maiden KJ, Chimimba LR, Smalley TJ (1986) Cuspate ore-wall rock interfaces, piercement structures, and the localization of some sulfide ores in deformed sulfide deposits. Econ Geol 81:1464-1472

Marshall B, Gilligan LB (1989) Durchbewegung structure, piercement cusps, and piercement veins in massive sulfide deposits: formation and interpretation. Econ Geol 84:2311-2319

McLennan SM, Taylor SR (1991) Sedimentary rocks and crustal evolution: Tectonic setting and secular trends. J Geol 99:1-21

Miller MF (2002) Isotopic fractionation and the quantification of 170 anomalies in the oxygen three-isotope system: an appraisal and geochemical significance. Geochim Cosmochim Acta 66:1881-1889

Morse JW, Berner RA (1995) What determines sedimentary C/S ratios? Geochim Cosmochim Acta 59:1073-1077

Moubray RJ, Brand EL, Hofmeyr PK, Potter M (1979) The Hunters Road nickel prospect. In: Anhaeusser CR, Foster RP, Stratten T (eds) A symposium on mineral deposits and the transportation and deposition of metals: Geol Soc S Afr Spec Publ 5:109-116

Moynier F, Blichert-Toft J, Telouk P, Luck JM, Albarede F (2007) Comparative stable isotope geochemistry of $\mathrm{Ni}, \mathrm{Cu}, \mathrm{Zn}$, and $\mathrm{Fe}$ in chondrites and iron meteorites. Geochim Cosmochim Acta 71:4365-4379

Naldrett A.J (1981) Nickel sulfide deposits: classification, composition, and genesis. Econ Geol 75:628-685

Naldrett AJ (1989) Magmatic sulfide deposits. Oxford University Press

Naldrett AJ (2004) Magmatic sulfide deposits: Geology, geochemistry, and exploration. Berlin, Springer 
1078 Ono S, Beukes NJ, Rumble D (2009) Origin of two distinct multiple-sulfur isotope compositions of pyrite in the 2.5 Ga Klein Naute Formation, Griqualand West Basin, South Africa. Precambrian Res 169:48-57

Pavlov AA, Kasting JF (2002) Mass-independent fractionation of sulfur isotopes in Archean sediments: strong evidence for an anoxic Archean atmosphere. Astrobiology 2:27-41

Planavsky NJ, Rouxel O, Bekker A, Hofmann A, Little C, Lyons TW (2012) Iron isotope composition of some Archean and Paleoproterozoic iron formations. Geochim Cosmochim Acta 80:158-169

Polyakov VB, Clayton RN, Horita J, Mineev SD (2007) Equilibrium iron isotope fractionation factors of minerals: Reevaluation from the data of nuclear inelastic resonant X-ray scattering and Mössbauer spectroscopy. Geochim Cosmochim Acta 71:3833-3846

Prendergast MD (2003) The nickeliferous late Archean Reliance komatiitic event in the Zimbabwe craton-magmatic architecture, physical volcanology, and ore genesis. Econ Geol 98:865-891

Rice A, Moore JM (2001) Physical modeling of the formation of komatiite-hosted nickel deposits and a review of the thermal erosion paradigm. Can Mineral 39:491-503

Rouxel O, Bekker A, Edwards K (2005) Iron Isotope Constraints on the Archean and Paleoproterozoic Ocean Redox State. Science 307:1088-1091

Rouxel O, Shanks WC, Bach W, Edwards K.J (2008) Integrated Fe and S-isotope study of seafloor hydrothermal vents at East Pacific rise 9-10 degrees N. Chem Geol 252:214-227

Schuessler JA, Schoenberg R, Behrens H, von Blanckenburg F (2007) The experimental calibration of the iron isotope fractionation factor between pyrrhotite and peralkaline rhyolitic melt. Geochim Cosmochim Acta 71:417-433

Severmann S, Lyons TW, Anbar A, McManus J, Gordon G (2008) Modern iron isotope perspective on the benthic iron shuttle and the redox evolution of ancient oceans. Geology $36: 487-490$

Siebert C, Nägler TF, Kramers JD (2001) Determination of molybdenum isotope fractionation by double-spike multicollector inductively coupled plasma mass spectrometry. Geochem Geophys Geosyst 2:2000GC000124

Stone WE, Archibald NJ (2004) Structural controls on nickel sulphide ore shoots in Archaean komatiite, Kambalda, WA: the volcanic trough controversy revisited. J Struct Geol 26:1173-1194

Tanimizu M, Hirata T (2006) Determination of natural isotopic variation in nickel using inductively coupled plasma mass spectrometry. J Anal At Spectrom 21:1423-1426 
1112 Tomkins AG (2010) Windows of metamorphic sulfur liberation in the crust: Implications for

1 gold deposit genesis. Geochim Cosmochim Acta 74:3246-3259

Tomschi HP (1987) Goldvorkommen im Archaischen Harare-Bindura-greenstone belt, Zimbabwe: Zusammenhänge zwischen Lagerstättenbildung und greenstone belt Entwicklung: PhD thesis, University of Köln

Trofimovs J, Davis BK, Cas RAF (2004) Contemporaneous ultramafic and felsic intrusive and extrusive magmatism in the Archaean Boorara Domain, Eastern Goldfields Superterrane, Western Australia, and its implications. Precambrian Res 131:283-304

Viljoen MJ, Bernasconi A (1979) The geochemistry, regional setting and genesis of the Shangani-Damba nickel deposits, Rhodesia. In: Anhaeusser CR, Foster RP, Stratten T (eds) A symposium on mineral deposits and the transportation and deposition of metals. Geol Soc S Afr Spec Publ 5:67-98

Viljoen MJ, Bernasconi A, van Coller N, Kinloch E, Viljoen RP (1976) The geology of the Shangani nickel deposit, Rhodesia. Econ Geol 71:76-95

Weyer S, Ionov DA (2007) Partial melting and melt percolation in the mantle: the message from Fe isotopes. Earth Planet Sci Lett 259:119-133

Williams DAC (1979) The association of some nickel sulfide deposits with komatiite volcanism in Rhodesia. Can Mineral 17:337-350

Williams DA, Kerr RC, Lesher CM (2011) Mathematical modeling of thermomechanical erosion beneath Proterozoic komatiitic basaltic sinuous rilles in the Cape Smith Belt, New Québec, Canada. Miner Deposita 46:943-958 


\section{Figure captions}

Fig. 1. Geological map of the Zimbabwe craton showing major nickel deposits.

Fig. 2. (A) Regional geological setting of the Shangani nickel deposit (after Viljoen and Bernasconi, 1979). (B) Detailed geology of the Shangani Mineralized Complex (after Viljoen and Bernasconi, 1979). (C) Detailed geological map of the southern portion of the Shangani Mineralized Complex (after Dirks and Sithole, 1996), showing a much more complex geometry for the lobes and stem. SLUC: Shangani Layered Ultramafic Complex.

Fig. 3. (A) Geological map of the southern part of the Bindura-Shamva greenstone belt, showing the main lithologies and the orientation of $\mathrm{L}_{1}$ and $\mathrm{L}_{2}$ lineations. Map is modified from Baglow (1992). (B) Map of the area around Trojan Mine (modified from Dirks and Jelsma, 1998) and cross-section through Cardiff Hill. MOB: Main Ore Body; HWOB: Hangingwall Ore Body; CSOB: Cardiff South Ore Body; CEOB: Cardiff East Ore Body; FW2OB: Footwall No. 2 Ore Body; CWOB: Cardiff West Ore Body; CFWOB: Cardiff Far West Ore Body.

Fig. 4. (A) Boudin of serpentinized ultramafic rock within sheared and sulfide-impregnated carbonaceous metashale. (B) Contact between sheared carbonaceous metashale (left) and serpentinite (right). A thin unit of carbonaceous metachert is present along the contact (center).

Fig. 5. Lower hemisphere stereographic projections of structural data from the Trojan Mine area. (A) $\mathrm{S}_{0}$ and $\mathrm{S}_{1}$; (B) $\mathrm{L}_{1}$ and $\mathrm{L}_{2}$; (C) mean orientations of the long axes of ore bodies constructed from mine plans (MOB: Main Ore Body, HWOB: Hanging Wall Ore Body, CSOB: Cardiff South Ore Body); (D) intersection between average $\mathrm{S}_{0}$ and $\mathrm{S}_{1}$ orientations. Note that the ore bodies are parallel to the $\mathrm{S}_{0}-\mathrm{S}_{1}$ intersection lineation.

Fig. 6. Geological plan of the $7^{\text {th }}$ level showing the distribution of the main ore bodies (modified from Chimimba, 1984). MOB: Main Ore Body; HWOB: Hangingwall Ore Body; CSOB: Cardiff South Ore Body; FW2OB: Footwall No. 2 Ore Body; CEOB: Cardiff East Ore Body; CFEOB: Cardiff Far East Ore Body. Note that the distribution of the CSOB and the 
1168 FW2OB along an inferred fold structure (Chimimba, 1984) is inconsistent with younging directions to the east as well as subsequent mapping (Fig. 3B).

Fig. 7. Geological plan of the 23/2 (A) and 25/3 (B) levels. MOB: Main Ore Body; HWOB: Hangingwall Ore Body.

Fig. 8. Photomicrographs of sulfide-bearing metasedimentary rocks. (A) Crenulated chloriteactinolite schist; sulfides (pyrrhotite and minor chalcopyrite) occur within the foliation plane (preferentially along fold hinges) and as veins cutting across the crenulations (plane-polarized light). (B) Chlorite-actinolite schist; sulfides (mainly pyrrhotite) are irregularly dispersed or occur in pressure shadows of actinolite (Act) porphyroblasts (plane-polarized light). (C) Chert cut by vein filled with quartz, actinolite and sulfides (pyrrhotite (Po) and chalcopyrite (Ccp); plane-polarized light). (D) same as in C (reflected light).

Fig. 9. Photomicrographs (reflected light) of sulfide-bearing ultramafic rocks. (A) Coarsegrained serpentine and tremolite are intergrown with sulfides (pyrrhotite (Po), pentlandite (Pn) and minor chalcopyrite). The sulfides form stringers parallel to $\mathrm{S}_{1}$. (B) Mesh texture of serpentinized dunite is cut by a sulfide vein. Sulfide in turn is also cut by magnetite (Mag) veins that are parallel to the mesh texture of the surrounding metadunite, suggesting that serpentinization and magnetite formation took place after sulfide veining. (C) Mesh texture of serpentinized dunite is cut by a sulfide vein with a weak fabric parallel to mesh texture indicating that veining took place prior to serpentinization. (D, E) Sulfide-bearing reaction rim between serpentinized dunite and massive talc-serpentine rock. (F) Globular sulfide blebs both interstitial and within serpentinized olivine. The globules are generally aligned along fractures.

Fig. 10. PAAS-normalized distribution of selected major and trace elements of the average clastic metasedimentary rock from Trojan Mine.

Fig. 11. Chondrite-normalized REE plots of clastic metasediment and metachert samples from the Trojan Mine area as well as the average compositions of rhyodacite of the Iron Mask Formation and basalt of the Arcturus Formation. 
1201 Fig. 12. $\mathrm{Cr} / \mathrm{Th}$ vs. $\mathrm{La}_{\mathrm{N}} / \mathrm{Yb}_{\mathrm{N}}$ diagram showing siliciclastic metasediments (filled circles), rhyodacite of the Iron Mask Formation (open squares), and basalt of the Arcturus Formation ${ }_{4}^{3} 1203$ (open triangles). Also shown is the average composition of the Iron Mask Formation ${ }_{6}^{5} 1204$ rhyodacite (filled square) and Arcturus Formation basalt (filled triangle) as well as a mixing 71205 trajectory between the two end-member compositions in steps of $10 \%$. Note that the Trojan 8

91206 Mine samples do not plot near the proposed mixing trajectory, thus not supporting a simple 10 mixing relationship between the two potential end-member compositions. Mine and (B) Shangani Mine. Dashed arrows indicate possible mixing trends.

Fig. 14. Plot of $\delta^{34} \mathrm{~S}$ vs. $\delta^{56} \mathrm{Fe}$ values for metasedimentary and ore sulfides from Trojan Mine (TM) and Shangani Mine (SM). 
1215 Table 1. Lithological description, mineralogy and structural features of the geological units around Trojan Mine.

\section{Ultramafic Serpentinite with rock locally preserved cumulate texture; pyroxenite occurs at the top of some ultramafic bodies; the primary grain size is mostly less than $3 \mathrm{~mm}$. \\ Massive serpentinite is composed of antigorite and talc with minor metamorphic olivine, tremolite, chromite and carbonate. Schist consists of talc, magnesite and antigorite, with minor chlorite, tremolite, magnetite and chromite. Quartz is locally common along fine fractures in magnetite-rich zones. \\ Cumulate-textured rock consists of closely packed antigorite rimmed by magnetite in a talcose matrix. Pyroxene in metapyroxenite is replaced by amphibole with minor chlorite and talc.}

$\begin{array}{ll}\begin{array}{l}\text { Silicified } \\ \text { meta- }\end{array} & \text { A. Various } \\ \text { sedimentary } & \text { metasedimentary } \\ \text { rocks } & \text { B. Metasandstone } \\ & \text { intercalated with } \\ & \text { metasedimentary } \\ & \text { schist. } \\ & \text { C. Black metachert and } \\ \text { carbonaceous schist } \\ \text { associated with } \\ \text { ultramafic rock. Chert } \\ \text { is well-layered to } \\ \text { massive. } \\ \text { D. Metaconglomerate } \\ \text { lenses (rare). }\end{array}$

Feldspathic Lensoidal bodies of schist schist associated with metasedimentary rocks.
A. Graphitic schist (chlorite, sericite, graphite, quartz, biotite), chlorite-sericite-quartz-feldspar schist, biotitetremolite/actinolite-quartz-feldspar schist, rare lenses of biotite-muscovite-cordierite-quartz schist. B. Quartz augen (rare sericitized feldspar augen) set in a matrix of quartz, plagioclase and biotite. Biotitefoliation is overgrown by unoriented, radiating aggregates of hornblende and up to $1 \mathrm{~cm}$ large, anhedral garnet.

C. Metachert consists of quartz with variable amounts of graphite, chlorite, sericite and carbonate. Carbonaceous schist is composed of quartz with variable amounts of aligned hornblende and biotite. D. Equal proportions of elongate, hornblende-bearing basaltic and quartz-feldspathic fragments embedded in a schistose, chlorite-carbonate-rich matrix.

Medium-grained ( $<3 \mathrm{~mm}$ ) hornblende intergrown with plagioclase with minor matrix quartz, biotite and secondary carbonate. Two generations of hornblende occur; an early one parallel to the regional foliation and a later unoriented one.
Strongly schistose anastomosing horizons exhibiting foliation truncations, S-C fabrics and intense disharmonic folding.

Schistose horizons parallel to the regional foliation. 


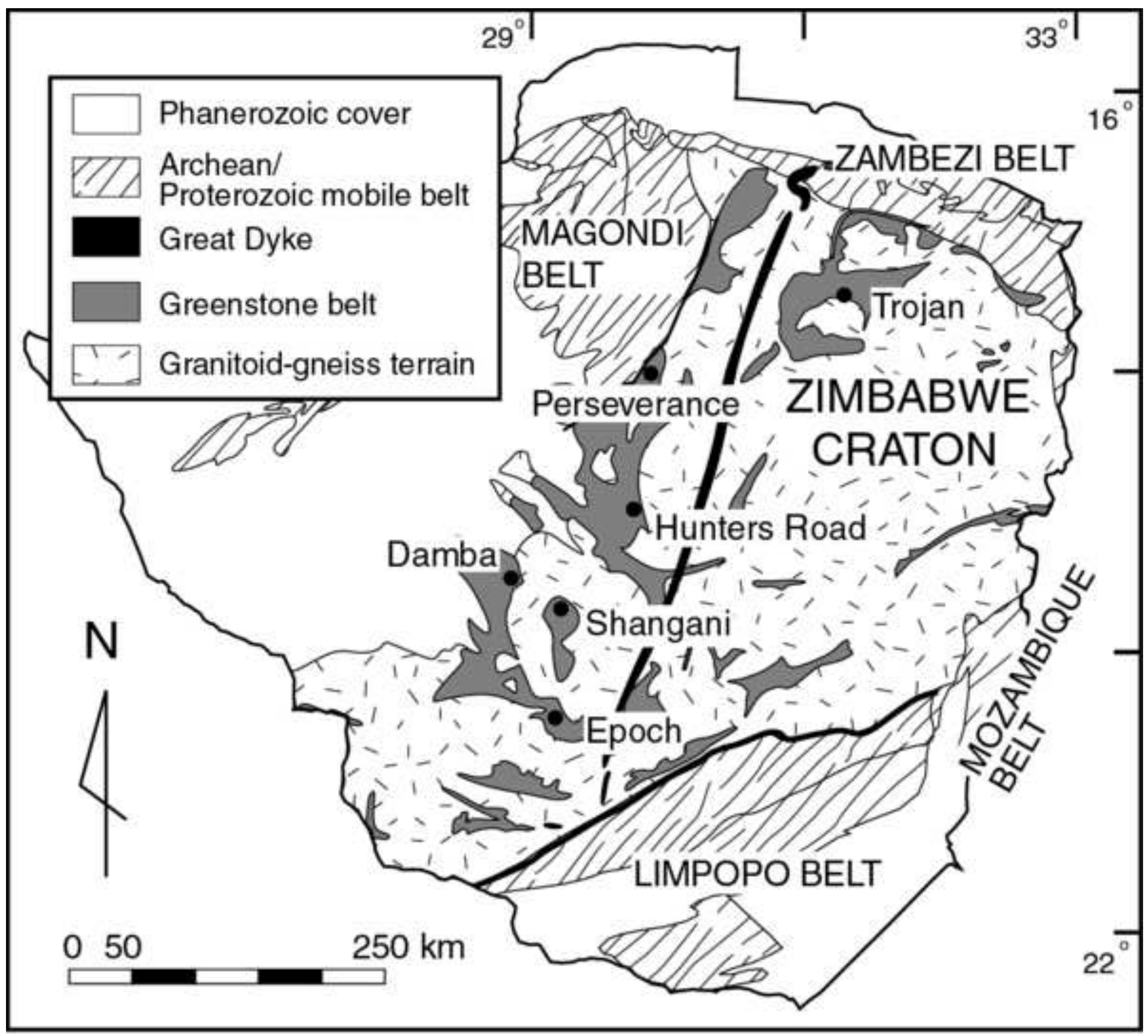






\section{Figure 3}

Click here to download high resolution image
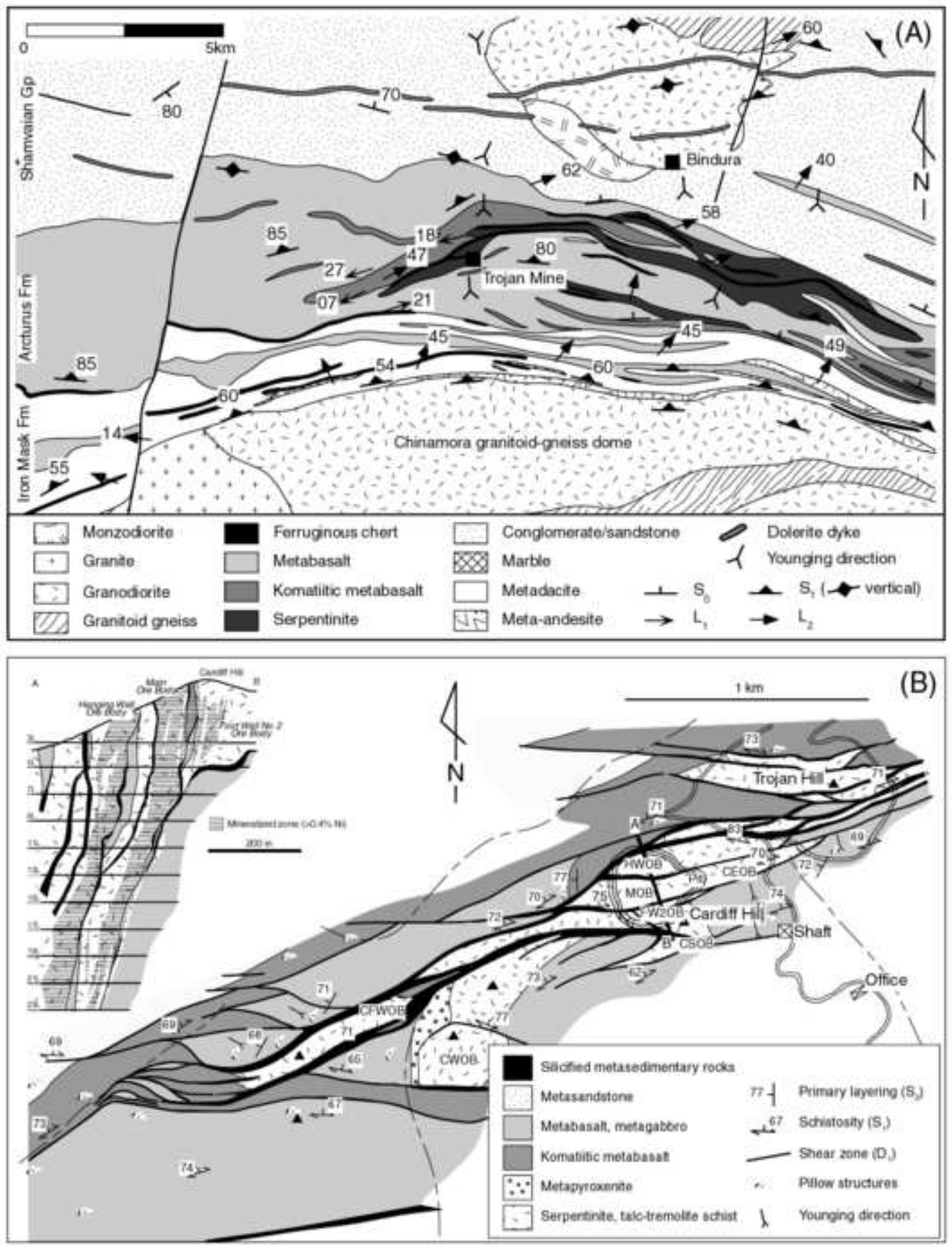
Click here to download high resolution image
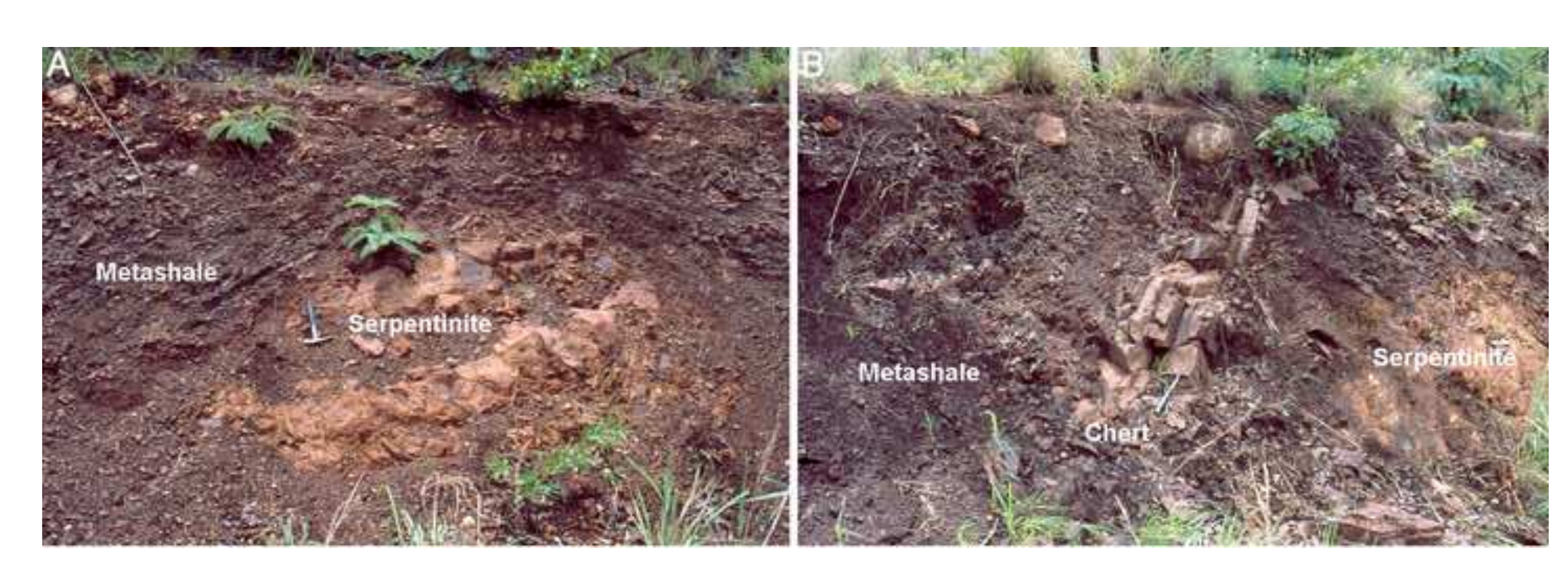

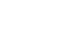



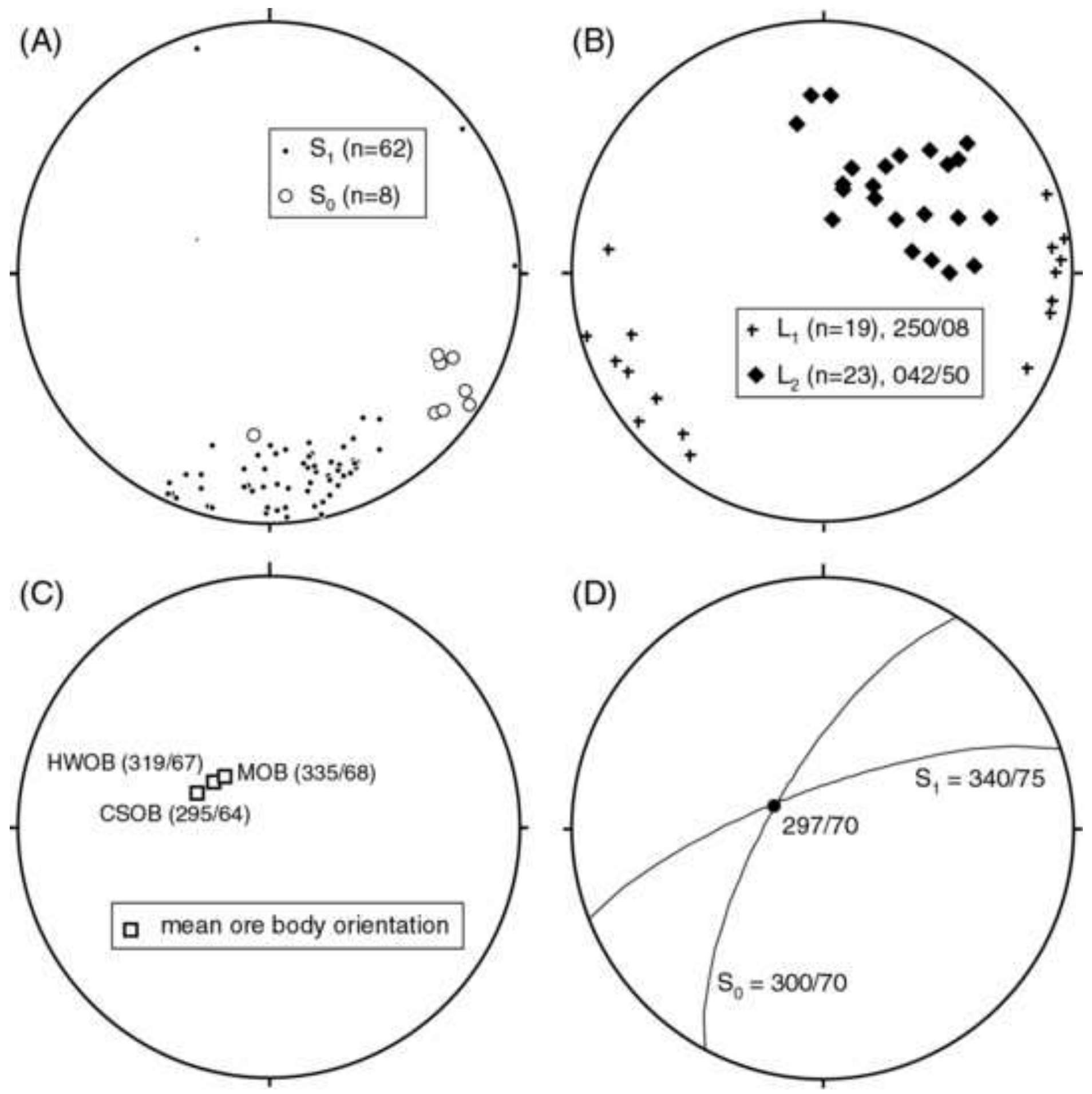


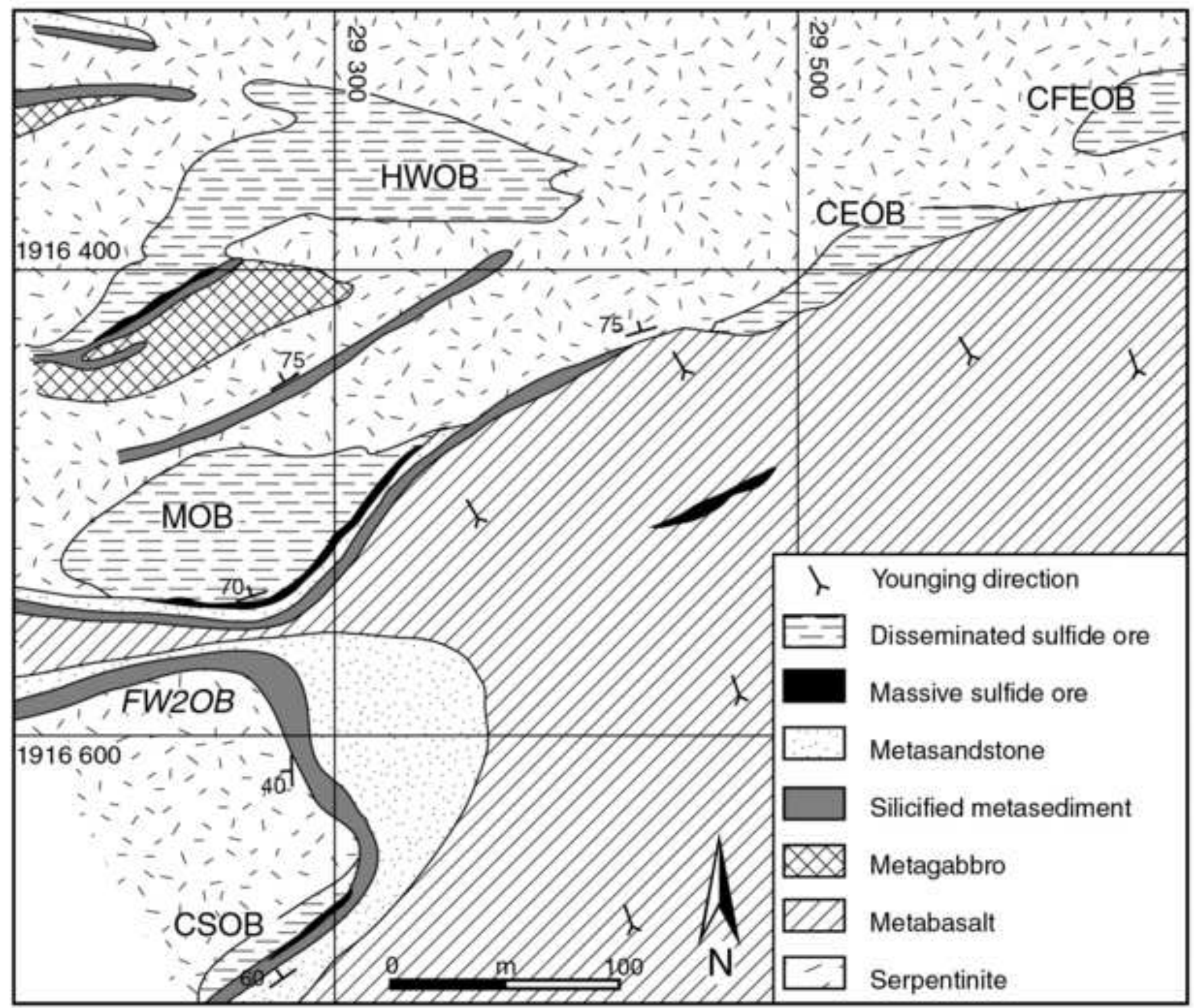




\section{Figure 7}

Click here to download high resolution image

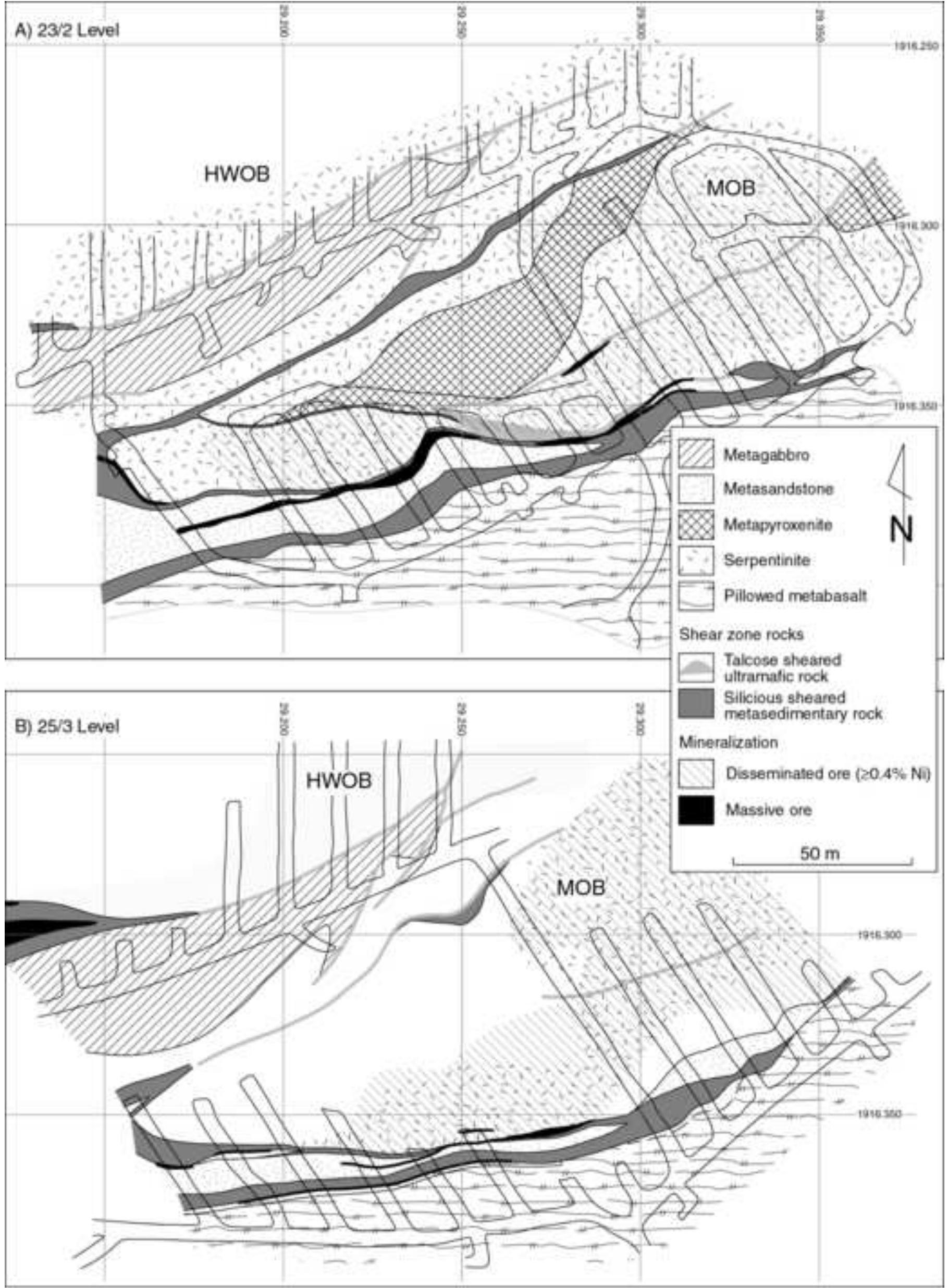


Click here to download high resolution image

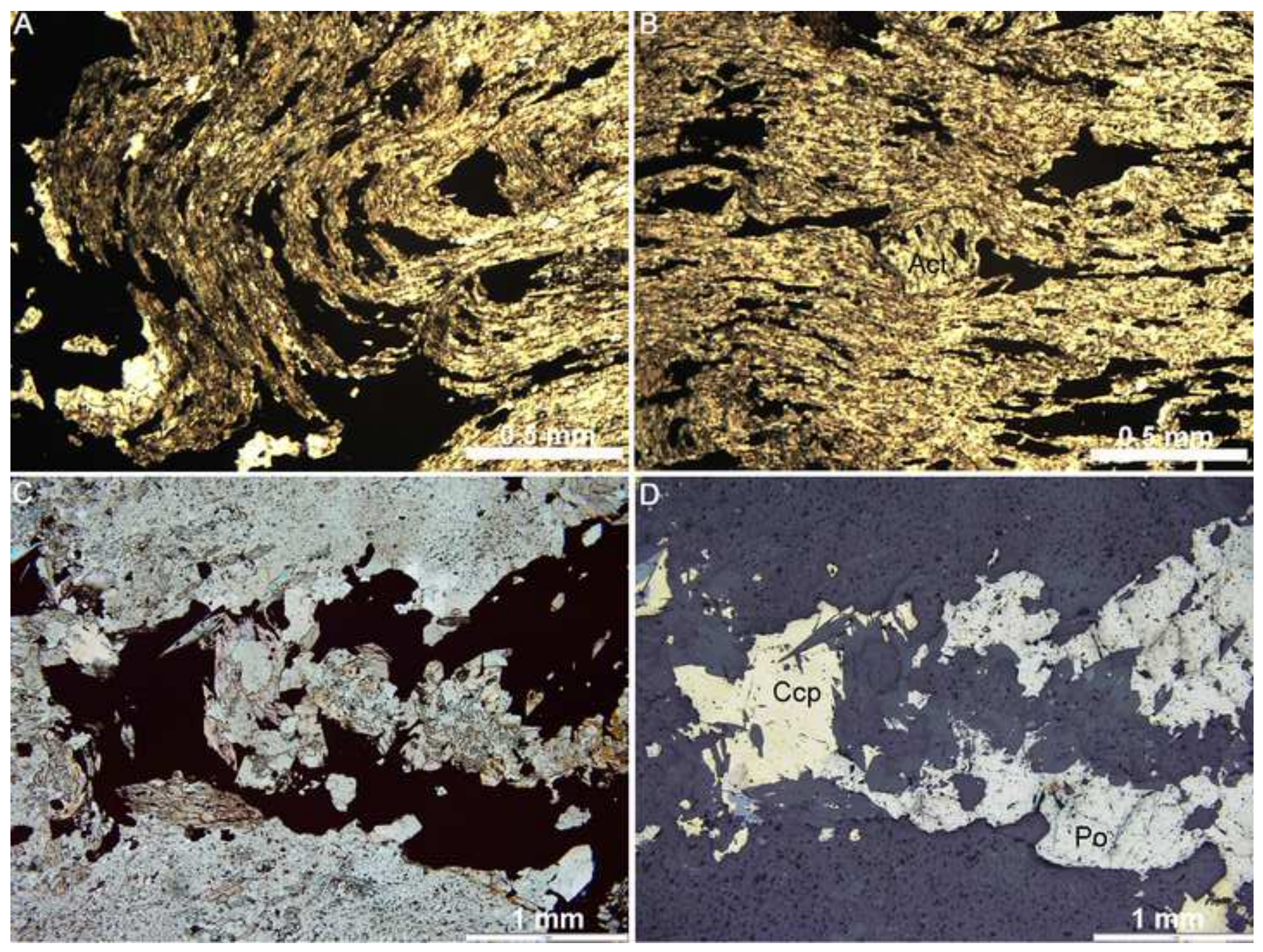



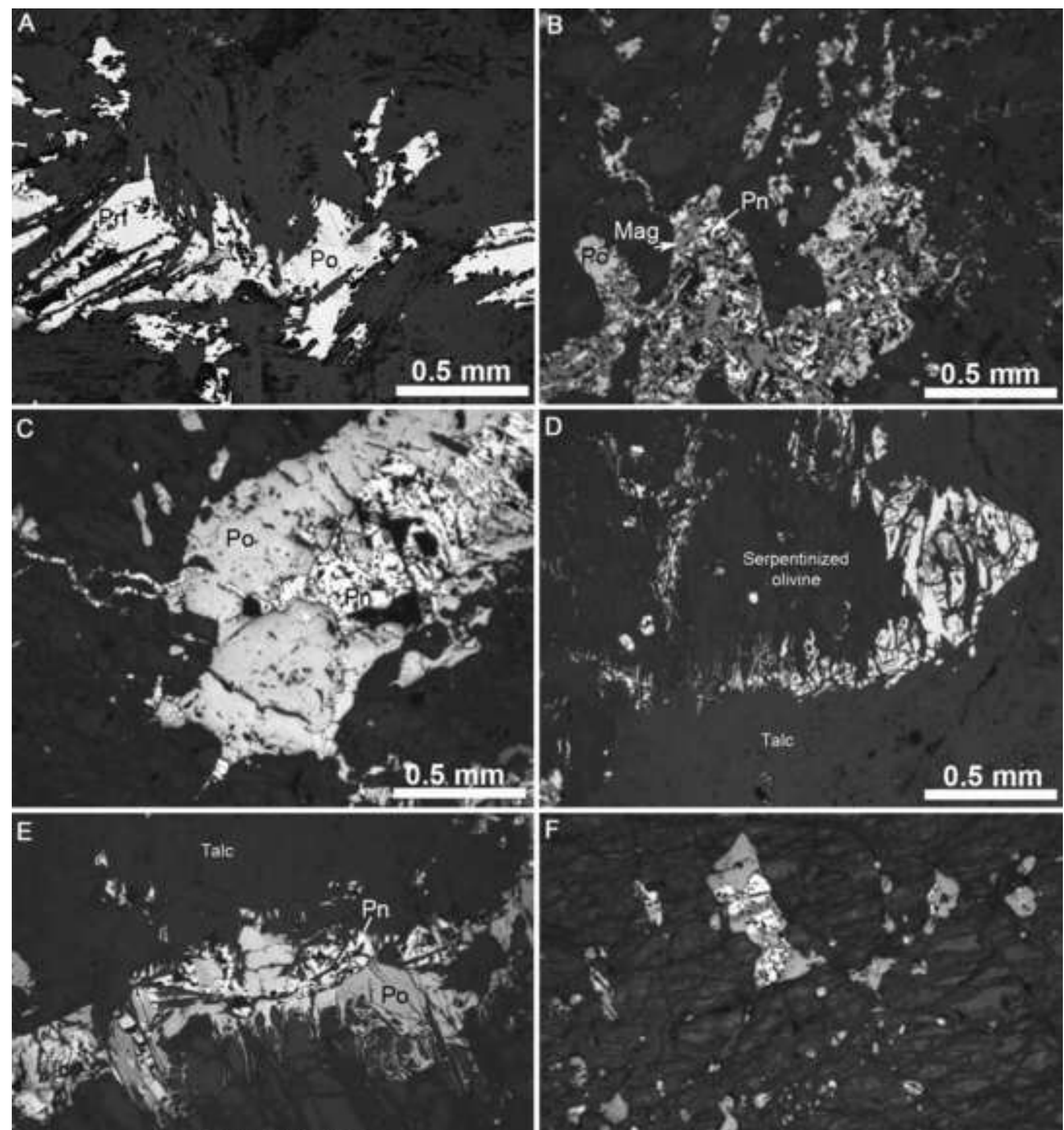

Setpentinized ollvine $0.5 \mathrm{~mm}$

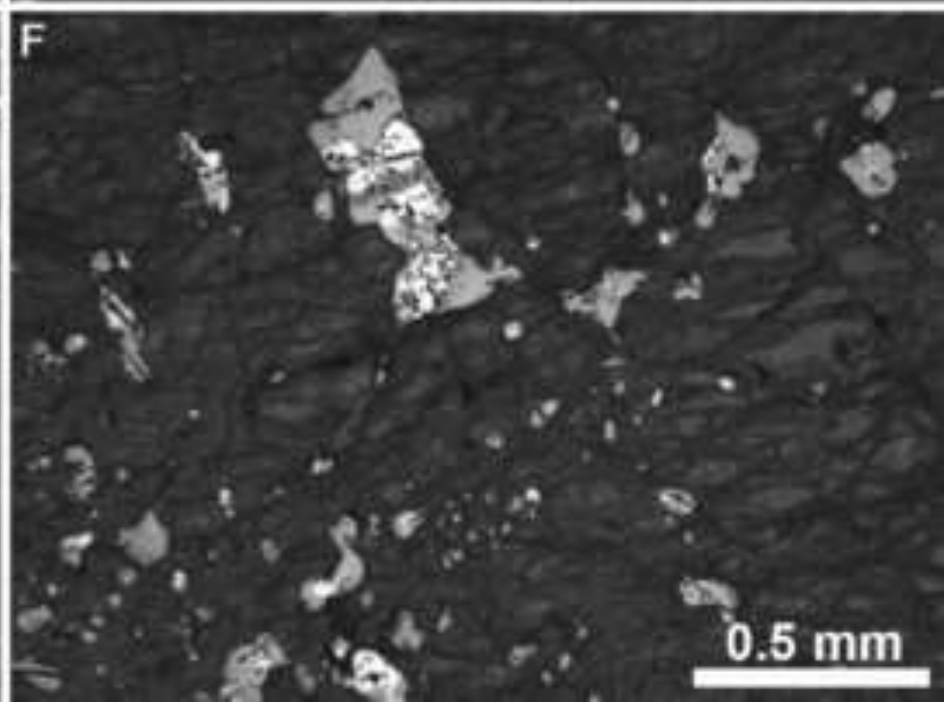









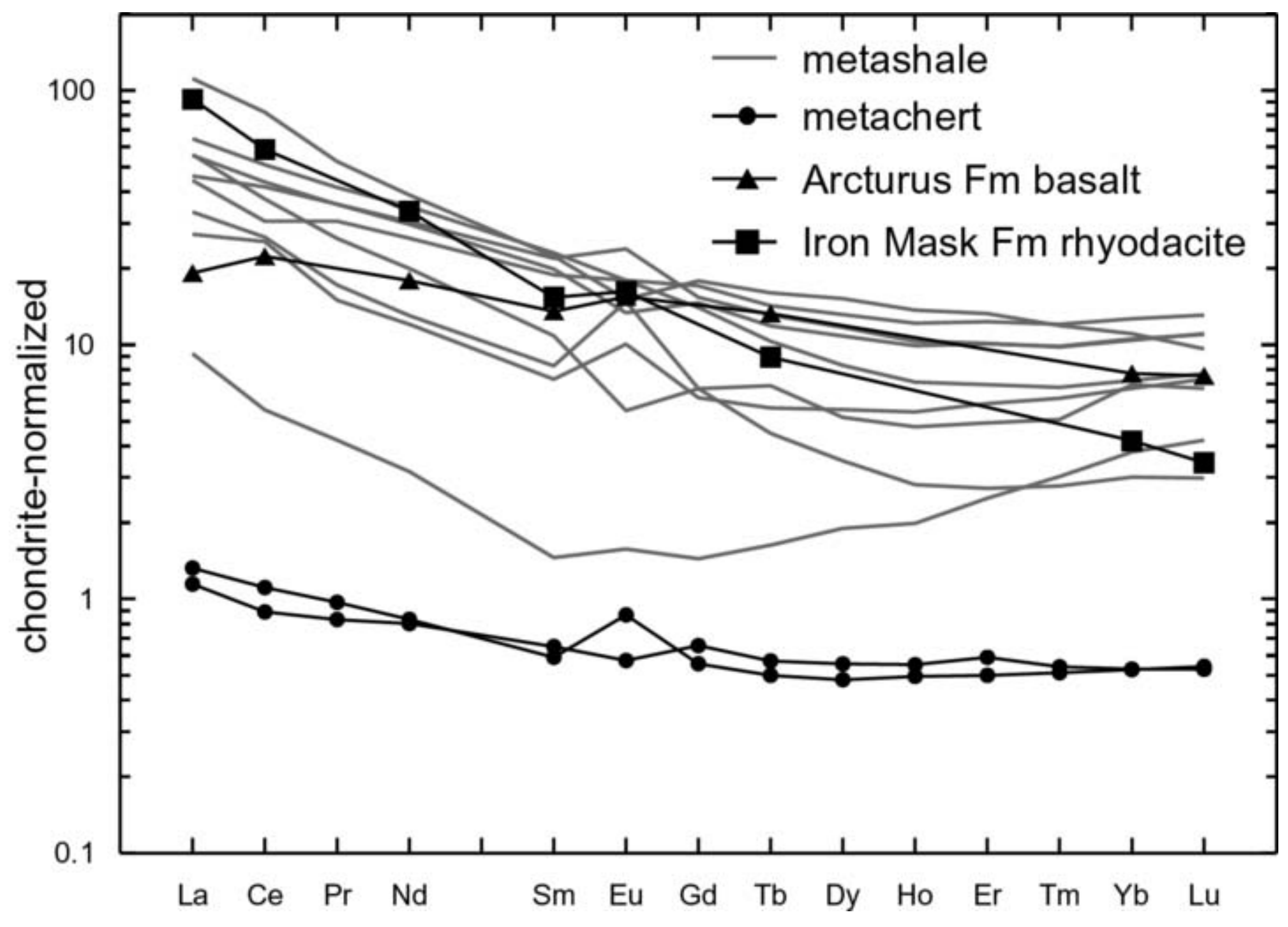




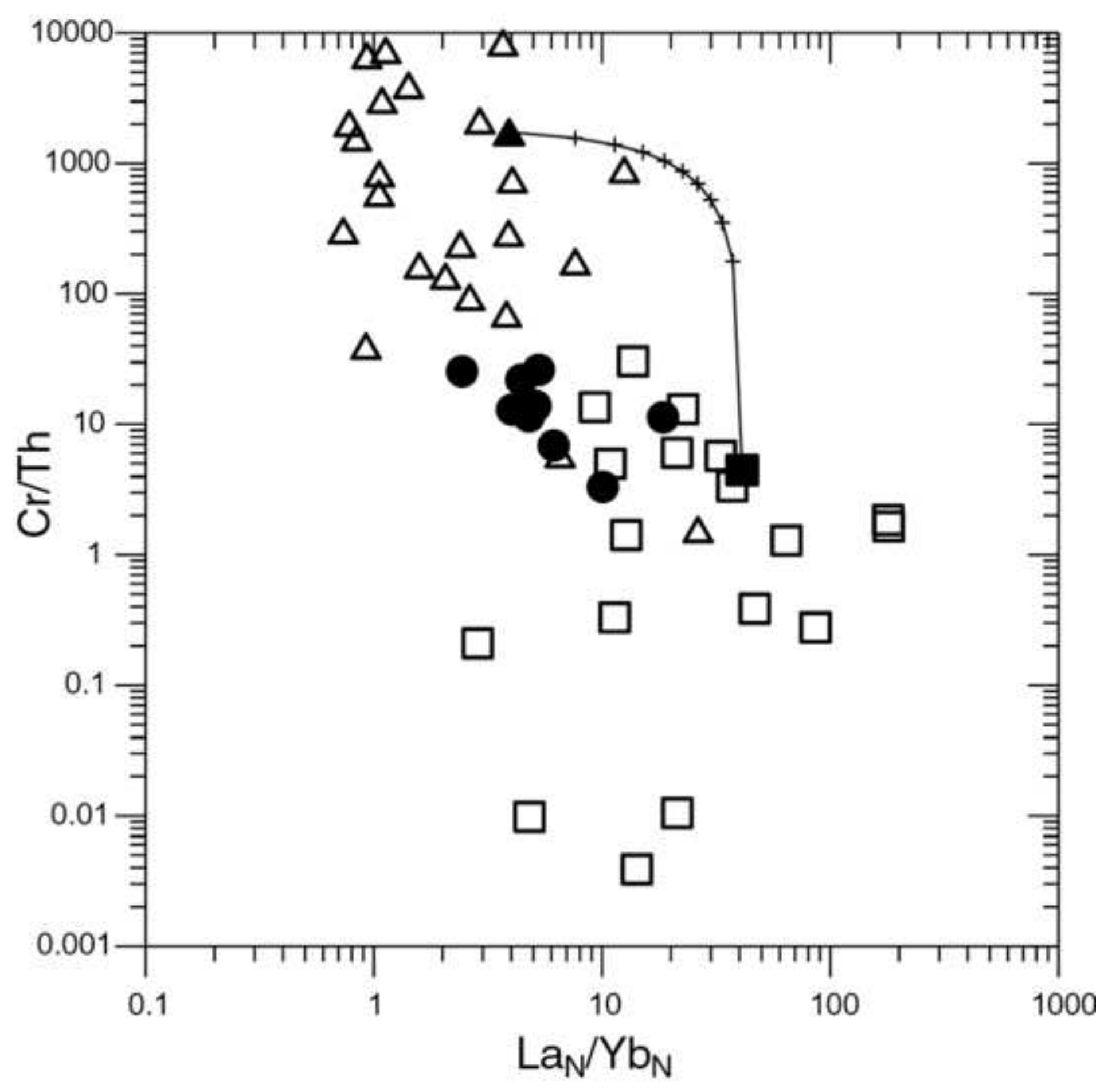



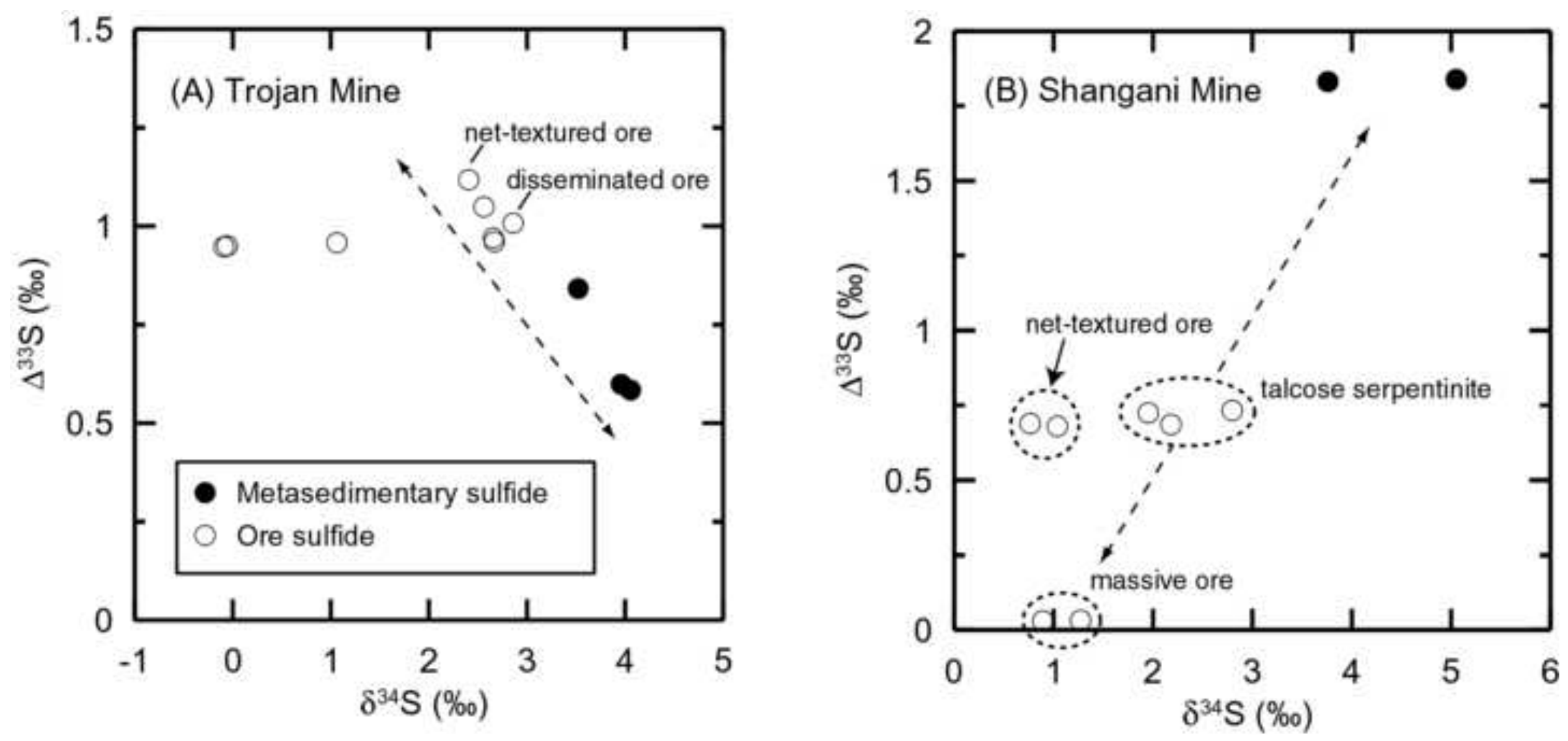





Table 2. Major element (in wt. \% oxide) and trace element (in ppm) concentrations of metasedimentary rocks from Trojan Mine.

\begin{tabular}{|c|c|c|c|c|c|c|c|c|c|c|c|}
\hline & $\begin{array}{l}\text { TM6.9 } \\
\text { shale }\end{array}$ & $\begin{array}{l}\text { TM7.5 } \\
\text { shale }\end{array}$ & $\begin{array}{l}\text { TM9.5 } \\
\text { shale }\end{array}$ & $\begin{array}{l}\text { TM12.7 } \\
\text { shale }\end{array}$ & $\begin{array}{l}\text { ZTR-2 } \\
\text { shale }\end{array}$ & $\begin{array}{l}\text { ZTR-3 } \\
\text { chert }\end{array}$ & $\begin{array}{l}\text { ZTR-4 } \\
\text { shale }\end{array}$ & $\begin{array}{l}\text { ZTR-6 } \\
\text { shale }\end{array}$ & $\begin{array}{l}\text { ZTR-7 } \\
\text { shale }\end{array}$ & $\begin{array}{l}\text { ZTR-8 } \\
\text { shale }\end{array}$ & $\begin{array}{l}\text { ZTR1 } \\
\text { chert }\end{array}$ \\
\hline$\overline{\mathrm{SiO}_{2}}$ & 65.65 & 60.74 & 61.62 & 63.37 & 48.20 & 88.19 & 70.05 & 81.97 & 73.92 & 56.02 & 98.26 \\
\hline $\mathrm{TiO}_{2}$ & 0.52 & 0.48 & 0.44 & 0.52 & 0.42 & 0.02 & 0.56 & 0.26 & 0.46 & 0.35 & 0.01 \\
\hline $\mathrm{Al}_{2} \mathrm{O}_{3}$ & 12.42 & 12.37 & 15.13 & 15.62 & 13.63 & 0.04 & 16.89 & 8.56 & 11.34 & 14.08 & $\mathrm{bd}$ \\
\hline $\mathrm{Fe}_{2} \mathrm{O}_{3}$ & 8.17 & 11.84 & 6.58 & 1.42 & 11.60 & 7.61 & 0.67 & 0.58 & 0.65 & 1.42 & 0.37 \\
\hline $\mathrm{MnO}$ & 0.12 & 0.15 & 0.11 & 0.03 & 0.05 & 0.02 & 0.04 & 0.02 & 0.01 & 0.03 & 0.01 \\
\hline $\mathrm{MgO}$ & 1.65 & 2.13 & 2.16 & 2.52 & 2.23 & 0.11 & 0.87 & 0.48 & 1.02 & 9.53 & $\mathrm{bd}$ \\
\hline $\mathrm{CaO}$ & 0.83 & 1.84 & 0.96 & 2.05 & 2.16 & 0.10 & 0.02 & 0.01 & 1.77 & 0.88 & 0.07 \\
\hline $\mathrm{Na}_{2} \mathrm{O}$ & 5.34 & 4.13 & 4.94 & 1.50 & 6.94 & 0.05 & 0.16 & 0.18 & 3.87 & 4.61 & $\mathrm{bd}$ \\
\hline $\mathrm{K}_{2} \mathrm{O}$ & 1.40 & 1.86 & 4.14 & 12.15 & 0.02 & bd & 5.49 & 2.83 & 0.12 & 0.03 & 0.12 \\
\hline $\mathrm{P}_{2} \mathrm{O}_{5}$ & 0.07 & 0.08 & 0.08 & 0.17 & 0.08 & 0.03 & 0.02 & 0.02 & 0.04 & 0.02 & bd \\
\hline LOI & 1.56 & 0.92 & 2.07 & 0.69 & 11.92 & 0.98 & 5.49 & 4.67 & 6.54 & 12.55 & 0.46 \\
\hline Total & 97.73 & 96.55 & 98.24 & 100.03 & 97.25 & 97.15 & 100.26 & 99.58 & 99.74 & 99.52 & 99.3 \\
\hline Sc & 12.5 & 13.1 & 10.5 & 8.0 & 28.2 & 0.1 & 6.4 & 5.5 & 8.2 & 6.7 & 0.1 \\
\hline V & 48.6 & 74.5 & 86.5 & 49.5 & 85.5 & 0.7 & 89.4 & 38.4 & 44.5 & 41.5 & 0.5 \\
\hline $\mathrm{Cr}$ & 80.4 & 120.4 & 78.5 & 23.9 & 114.4 & 0.8 & 59.4 & 44.2 & 54.9 & 56.1 & 0.9 \\
\hline Co & 26.9 & 40.5 & 29.0 & 3.3 & 65.5 & 15.2 & 0.8 & 0.2 & 4.1 & 8.2 & 0.9 \\
\hline $\mathrm{Ni}$ & 93.5 & 83.9 & 50.4 & 7.9 & 224.5 & 41.3 & 20.4 & 12.3 & 38.9 & 419.0 & 5.5 \\
\hline $\mathrm{Cu}$ & 196 & 354 & 268 & 145 & 357 & 751 & 22 & 18 & 189 & 361 & 21 \\
\hline $\mathrm{Zn}$ & 3639 & 1695 & 5191 & 117 & 11881 & 226 & 60 & 26 & 113 & 2848 & 17 \\
\hline $\mathrm{Rb}$ & 59.8 & 94.2 & 75.3 & 160.7 & 0.4 & 0.1 & 98.6 & 61.4 & 1.3 & 0.3 & 0.1 \\
\hline $\mathrm{Sr}$ & 109.4 & 128.6 & 61.3 & 233.6 & 83.2 & 0.7 & 11.1 & 10.8 & 134.3 & 64.3 & 1.2 \\
\hline$Y$ & 24.2 & 20.7 & 11.8 & 25.2 & 20.5 & 1.3 & 3.3 & 4.8 & 9.1 & 14.1 & 1.1 \\
\hline $\mathrm{Zr}$ & 222.2 & 168.7 & 162.4 & 223.4 & 110.9 & 0.4 & 200.9 & 100.3 & 167.3 & 135.4 & 2.6 \\
\hline $\mathrm{Nb}$ & 9.62 & 5.74 & 4.96 & 8.25 & 4.86 & 0.03 & 8.74 & 5.36 & 7.23 & 4.04 & 0.05 \\
\hline $\mathrm{Ba}$ & 67 & 79 & 286 & 1486 & 17 & 1 & 318 & 350 & 69 & 28 & 4 \\
\hline La & 20.0 & 17.2 & 8.4 & 34.4 & 14.3 & 0.4 & 2.9 & 17.3 & 10.3 & 13.7 & 0.4 \\
\hline $\mathrm{Ce}$ & 41.2 & 35.3 & 20.5 & 66.2 & 33.6 & 0.7 & 4.5 & 30.2 & 21.3 & 24.6 & 0.9 \\
\hline $\operatorname{Pr}$ & 5.07 & 4.34 & 1.82 & 6.41 & 4.35 & 0.10 & 0.51 & 3.19 & 2.09 & 3.73 & 0.12 \\
\hline $\mathrm{Nd}$ & 20.93 & 17.80 & 7.20 & 23.21 & 18.26 & 0.48 & 1.90 & 11.94 & 7.80 & 15.73 & 0.50 \\
\hline $\mathrm{Sm}$ & 4.47 & 3.86 & 1.42 & 4.33 & 4.26 & 0.13 & 0.28 & 2.11 & 1.61 & 3.67 & 0.11 \\
\hline $\mathrm{Eu}$ & 1.31 & 0.98 & 0.74 & 1.11 & 1.74 & 0.04 & 0.12 & 0.40 & 1.08 & 1.31 & 0.06 \\
\hline $\mathrm{Gd}$ & 4.41 & 3.78 & 1.60 & 4.61 & 3.97 & 0.17 & 0.37 & 1.74 & 1.74 & 3.62 & 0.14 \\
\hline $\mathrm{Tb}$ & 0.67 & 0.56 & 0.27 & 0.76 & 0.62 & 0.03 & 0.08 & 0.21 & 0.33 & 0.49 & 0.02 \\
\hline Dy & 4.23 & 3.48 & 1.79 & 4.88 & 3.76 & 0.18 & 0.61 & 1.12 & 1.67 & 2.67 & 0.15 \\
\hline $\mathrm{Ho}$ & 0.87 & 0.71 & 0.39 & 0.98 & 0.74 & 0.04 & 0.14 & 0.20 & 0.34 & 0.51 & 0.04 \\
\hline $\mathrm{Er}$ & 2.58 & 2.11 & 1.23 & 2.78 & 2.12 & 0.12 & 0.52 & 0.57 & 1.03 & 1.46 & 0.10 \\
\hline $\mathrm{Tm}$ & 0.39 & 0.32 & 0.20 & 0.39 & 0.32 & 0.02 & 0.10 & 0.09 & 0.16 & 0.22 & 0.02 \\
\hline $\mathrm{Yb}$ & 2.64 & 2.20 & 1.40 & 2.30 & 2.17 & 0.11 & 0.79 & 0.63 & 1.45 & 1.51 & 0.11 \\
\hline Lu & 0.42 & 0.35 & 0.24 & 0.31 & 0.36 & 0.02 & 0.14 & 0.10 & 0.22 & 0.25 & 0.02 \\
\hline $\mathrm{Hf}$ & 5.36 & 4.19 & 4.19 & 5.32 & 2.81 & bd & 4.91 & 2.64 & 4.14 & 3.43 & 0.02 \\
\hline $\mathrm{Ta}$ & 0.69 & 0.40 & 0.55 & 0.57 & 0.39 & bd & 0.63 & 0.40 & 0.61 & 0.34 & 0.00 \\
\hline w & 0.21 & 0.23 & 1.29 & 1.08 & 0.57 & 0.06 & 3.27 & 1.37 & 1.03 & 0.50 & 0.02 \\
\hline $\mathrm{Pb}$ & 198.5 & 118.9 & 123.7 & 61.2 & 51.6 & 332.2 & 6.7 & 29.4 & 16.4 & 27.4 & 0.9 \\
\hline Th & 5.83 & 4.61 & 6.08 & 7.22 & 5.22 & 0.03 & 2.33 & 3.92 & 4.78 & 8.19 & 0.01 \\
\hline U & 1.85 & 1.36 & 2.49 & 3.20 & 1.71 & 0.08 & 2.22 & 1.18 & 1.95 & 1.31 & 0.04 \\
\hline
\end{tabular}


Table 3. Description of samples used for sulfur, iron and nickel isotope and element concentration analyses and analytical results. Py, pyrite; Ccp, chalcopyrite; Po, pyrrhotite; Pn, pentlandite.

\begin{tabular}{|c|c|c|c|c|c|c|c|c|c|c|c|c|c|c|}
\hline \multirow{2}{*}{$\begin{array}{l}\text { Drillcore } \\
\text { Trojan Mine }\end{array}$} & \multirow[t]{2}{*}{ Depth $(m)$} & \multirow[t]{2}{*}{ Sample \# } & \multirow[t]{2}{*}{ Rock type } & \multirow[t]{2}{*}{$\delta^{34} S^{*}$} & \multirow[t]{2}{*}{$\delta^{33} S^{*}$} & \multirow[t]{2}{*}{$\Delta^{33} \operatorname{SIn}$} & \multicolumn{2}{|c|}{$\delta^{56 / 54} \mathrm{Fe} \delta^{57 / 54} \mathrm{Fe}$} & \multirow[t]{2}{*}{$\delta^{60 / 58} \mathrm{Ni}$} & \multicolumn{5}{|c|}{$\mathrm{S}(\mathrm{wt} \%) \mathrm{Fe}(\mathrm{wt} \%), \mathrm{Ni}(\mathrm{wt} \%) \mathrm{Cu}$ (wt\%', Sulphide type } \\
\hline & & & & & & & & & & & & & & \\
\hline $35-1-20$ & 7.5 & TM7.5 & silicious meta-greywacke & 3.5 & 2.7 & 0.84 & -1.41 & -2.12 & & 37.29 & 59.44 & 0.04 & 0.02 & $2 \mathrm{~mm}$ layer of $\mathrm{Po}$ \\
\hline $35-1-20$ & 9.5 & TM9.5 & silicious meta-shale & 4.1 & 2.7 & 0.58 & -1.52 & -2.24 & & 33.81 & 54.14 & 0.05 & 0.40 & Po nodule \\
\hline $35-1-20$ & 10.4 & TM10.4 & silicious meta-greywacke & 4.0 & 2.6 & 0.60 & -1.36 & -2.12 & & 14.38 & 25.04 & 0.02 & 0.15 & Po veinlets \\
\hline $35-1-20$ & 20.4 & TM20.4 & massive ore & 2.6 & 2.4 & 1.05 & 0.07 & 0.14 & -0.40 & 35.52 & 41.36 & 16.88 & 0.51 & Po-Pn \\
\hline $35-1-20$ & 20.8 & TM20.8 & massive ore & 1.1 & 1.5 & 0.96 & 0.03 & -0.01 & -0.39 & 35.90 & 42.80 & 16.44 & 0.41 & Po-Pn \\
\hline $35-1-20$ & 22.55 & TM22.55 & massive ore & 2.7 & 2.3 & 0.96 & -0.18 & -0.26 & -0.43 & 36.78 & 47.52 & 8.94 & 0.62 & Po-Pn \\
\hline $35-1-20$ & 25.6 & TM25.6 & massive ore & -0.1 & 0.9 & 0.95 & -0.22 & -0.32 & -0.38 & 36.73 & 48.02 & 8.72 & 0.36 & Po-Pn \\
\hline $35-1-20$ & 27.9 & TM27.9 & massive ore & -0.1 & 0.9 & 0.95 & -0.08 & -0.15 & & 37.14 & 47.98 & 10.10 & 0.35 & Po-Pn \\
\hline $35-1-20$ & 30.55 & TM30.55 & massive ore & 2.7 & 2.3 & 0.97 & -0.07 & -0.16 & & 36.23 & 45.03 & 12.77 & 0.63 & Po-Pn \\
\hline $35-1-20$ & 34.2 & TM34.2 & net-textured ore, serpentinite & 2.4 & 2.4 & 1.12 & -0.28 & -0.44 & -0.28 & 31.89 & 39.59 & 15.10 & 0.03 & Po-Pn \\
\hline $35-1-20$ & 37.9 & TM37.9 & disseminated ore, serpentinite & 2.9 & 2.5 & 1.01 & -0.18 & -0.27 & & 14.18 & 24.55 & 1.91 & 0.26 & Po \\
\hline Shangani Mine & & & & & & & & & & & & & & \\
\hline hand specimen & & FWOB-1 & carbonaceous shale & 5.1 & 4.4 & 1.84 & -0.25 & -0.37 & & 30.07 & 25.81 & 0.01 & 0.00 & cubic Py forming nodules \\
\hline hand specimen & & FWOB-2 & carbonaceous shale & 3.8 & 3.8 & 1.83 & -1.41 & -2.09 & & 33.85 & 51.02 & 0.11 & 0.11 & cubic Py-Po forming nodules \\
\hline hand specimen & & MOB-1 & massive ore & 0.9 & 0.5 & 0.03 & 0.26 & 0.42 & & 33.80 & 29.18 & 0.25 & 29.09 & Ссp \\
\hline hand specimen & & MOB-3 & massive ore & 1.3 & 0.7 & 0.03 & 0.25 & 0.34 & & 34.81 & 30.70 & 0.22 & 31.06 & Сср \\
\hline hand specimen & & MOB-2 & net-textured ore, serpentinite & 0.8 & 1.1 & 0.69 & 0.58 & 0.87 & -0.47 & 32.45 & 33.47 & 23.83 & 0.13 & Po-Pn \\
\hline hand specimen & & MOB-2B & net-textured ore, serpentinite & 1.0 & 1.2 & 0.68 & -0.10 & -0.22 & & 34.03 & 42.41 & 13.53 & 0.04 & Po-Pn \\
\hline 855/SOW & 8.9 & 855-MOB-8.9 & talcose serpentinite & 2.2 & 1.8 & 0.69 & 0.04 & 0.08 & & 7.61 & 7.18 & 0.07 & 0.01 & Po in carbonate vein \\
\hline $855 / \mathrm{SOW}$ & 56.7 & MOB-56.7 & talcose serpentinite & 2.8 & 2.2 & 0.73 & -0.75 & -1.11 & & 31.69 & 32.98 & 14.35 & 0.22 & blebs/veinlets of Po-Pn \\
\hline $855 / \mathrm{SOW}$ & 103 & 855-MOB-103 & talcose serpentinite & 2.0 & 1.7 & 0.72 & -0.02 & 0.00 & & 33.07 & 31.03 & 4.96 & 1.36 & blebs/veinlets of Po-Pn \\
\hline
\end{tabular}

$\delta^{33} S^{*}$ and $\delta^{34} S^{*}$ are defined as $\delta^{x} S^{*}=1,000 \ln \left(\left[\delta^{x} S / 1,000\right]+1\right)$, where $x$ is 33 and 34, respectively (cf. Miller, 2002).

$\delta^{33} S$ and $\delta^{34} S$ are conventional $\delta$ notations with respect to VCDT defined as $\delta^{x} S=1,000\left[\left({ }^{x} S /{ }^{32} S\right)_{\text {sample }} /\left({ }^{x} S /^{32} S\right)_{V C D T}-1\right]$,

where $x$ is 33 and 34 , respectively. $\Delta^{33} S_{\ln } \approx \delta^{33} S^{*}-0.515^{*} \delta^{34} S^{*}$ 